\title{
Development of Diesel Exhaust Aftertreatment System for Tier II Emissions
}

R. C. Yu, A. S. Cole, B. J. Stroia and S. C. Huang Cummins, Inc.

Ken Howden and Steve Chalk Department of Energy, Office of Advanced Automotive Technologies

Reprinted From: Proceedings of the 2002 Future Car Congress on CD-ROM (FCC2002CD) 
The appearance of this ISSN code at the bottom of this page indicates SAE's consent that copies of the paper may be made for personal or internal use of specific clients. This consent is given on the condition, however, that the copier pay a per article copy fee through the Copyright Clearance Center, Inc. Operations Center, 222 Rosewood Drive, Danvers, MA 01923 for copying beyond that permitted by Sections 107 or 108 of the U.S. Copyright Law. This consent does not extend to other kinds of copying such as copying for general distribution, for advertising or promotional purposes, for creating new collective works, or for resale.

Quantity reprint rates can be obtained from the Customer Sales and Satisfaction Department.

To request permission to reprint a technical paper or permission to use copyrighted SAE publications in other works, contact the SAE Publications Group.

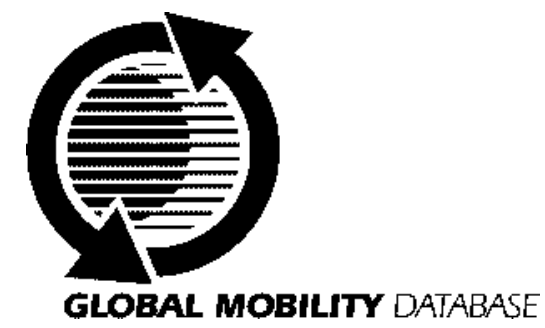

All SAE papers, standards, and selected books are abstracted and indexed in the Global Mobility Database

No part of this publication may be reproduced in any form, in an electronic retrieval system or otherwise, without the prior written permission of the publisher.

\section{ISSN 0148-7191}

Copyright $\odot 2002$ Society of Automotive Engineers, Inc.

Positions and opinions advanced in this paper are those of the author(s) and not necessarily those of SAE. The author is solely responsible for the content of the paper. A process is available by which discussions will be printed with the paper if it is published in SAE Transactions. For permission to publish this paper in full or in part, contact the SAE Publications Group.

Persons wishing to submit papers to be considered for presentation or publication through SAE should send the manuscript or a 300 word abstract of a proposed manuscript to: Secretary, Engineering Meetings Board, SAE.

\section{Printed in USA}




\title{
Development of Diesel Exhaust Aftertreatment System for Tier II Emissions
}

\author{
R. C. Yu, A. S. Cole, B. J. Stroia and S. C. Huang \\ Cummins, Inc. \\ Ken Howden and Steve Chalk \\ Department of Energy, Office of Advanced Automotive Technologies
}

Copyright (@ 2002 Society of Automotive Engineers, Inc.

\begin{abstract}
Due to their excellent fuel efficiency, reliability, and durability, compression ignition direct injection (CIDI) engines have been used extensively to power almost all highway trucks, urban buses, off-road vehicles, marine carriers, and industrial equipment. CIDI engines burn 35 to $50 \%$ less fuel than gasoline engines of comparable size, and they emit far less greenhouse gases (Carbon Dioxides), which have been implicated in global warming. Although the emissions of CIDI engines have been reduced significantly over the last decade, there remains concern with the Nitrogen Oxides $\left(\mathrm{NO}_{\mathrm{X}}\right)$ and Particulate Matter (PM) emission levels. In 2000, the US EPA proposed very stringent emissions standards to be introduced in 2007 along with low sulfur $(<15 \mathrm{ppm})$ diesel fuel. The California Air Resource Board (CARB) has also established the principle that future diesel fueled vehicles should meet the same emissions standards as gasoline fueled vehicles and the EPA followed suit with its Tier II emissions regulations.
\end{abstract}

Meeting the Tier II standards requires $\mathrm{NO}_{x}$ and $\mathrm{PM}$ emissions to be reduced dramatically. Achieving such low emissions while minimizing fuel economy penalty cannot be done through engine development and fuel reformulation alone, and requires application of $\mathrm{NO}_{x}$ and PM aftertreatment control devices. A joint effort was made between Cummins Inc. and the Department of Energy to develop the generic aftertreatment subsystem technologies applicable for Light-Duty Vehicle (LDV) and Light-Duty Truck (LDT) engines. This paper provides an update on the progress of this joint development program.

Three $\mathrm{NO}_{x}$ reduction technologies including plasmaassisted catalytic $\mathrm{NO}_{x}$ reduction (PACR), active lean $\mathrm{NO}_{x}$ catalyst (LNC), and adsorber catalyst (AC) technology using intermittent rich conditions for $\mathrm{NO}_{x}$ reduction were investigated in parallel in an attempt to select the best $\mathrm{NO}_{x}$ control approach for light-duty aftertreatment subsystem integration and development. Investigations included system design and analysis, critical lab/engine experiments, and ranking then selection of $\mathrm{NO}_{x}$ control technologies against reliability, up-front cost, fuel economy, service interval/serviceability, and size/weight. The results of the investigations indicate that the best $\mathrm{NO}_{x}$ control approach for LDV and LDT applications is a $\mathrm{NO}_{x}$ adsorber system. A greater than $83 \% \mathrm{NO}_{\mathrm{x}}$ reduction efficiency is required to achieve $0.07 \mathrm{~g} / \mathrm{mile} \mathrm{NO}_{\mathrm{x}}$ Tier II vehicle-out emissions. Both active lean $\mathrm{NO}_{x}$ and PACR technology are currently not capable of achieving the high conversion efficiency required for Tier II, Bin 5 emissions standards.

In this paper, the $\mathrm{NO}_{\mathrm{x}}$ technology assessment and selection is first reviewed and discussed. Development of the selected $\mathrm{NO}_{\mathrm{X}}$ technology ( $\mathrm{NO}_{\mathrm{X}}$ adsorber) and $\mathrm{PM}$ control are then discussed in more detail. Discussion includes exhaust sulfur management, further adsorber formulation development, reductant screening, diesel particulate filter development \& active regeneration, and preliminary test results on the selected integrated $\mathrm{SO}_{\mathrm{X}}$ trap, $\mathrm{NO}_{x}$ adsorber, and diesel particulate filter system over an FTP-75 emissions cycle, and its impact on fuel economy. Finally, the direction of future work for continued advanced aftertreatment technology development is discussed.

\section{INTRODUCTION}

The key objective of this program is to develop and understand the generic aftertreatment technologies applicable for LDV and LDT engines ranging from $55 \mathrm{~kW}$ to $200 \mathrm{~kW}$, and to demonstrate the capability of the selected aftertreatment technologies in meeting Tier II, Bin 5 emission standards. This involves engines with displacements ranging from 1.2 to 6.0 liters. A fundamental and "displacement-size" transparent understanding is required. The 5.9 liter Cummins ISB and 1.2 liter Ford DIATA engines were selected for aftertreatment subsystem development. The DIATA engine was developed under the Ford Hybrid Propulsion System Development Program. Specifications for the engines are provided in Figure 1. Test results confirmed 
that the LDV and LDT exhaust operating characteristics can be simulated with the Cummins ISB mule engines, as shown in Figure 2. Therefore, most of the aftertreatment subsystem screening and fundamental understanding has been conducted on the ISB mule engines. The typical engine-out $\mathrm{NO}_{x}$ contribution as a function of exhaust gas catalyst-in and mean catalyst temperatures for the FTP-75 cycle is given in Figure 3 . Among all the engine exhaust characteristics, exhaust temperature plays the most dominant role on exhaust emission control device performance. In addition to the fundamental work, parallel performance validation and system optimization has been conducted on a DIATA engine. The program's primary focus is on aftertreatment subsystem $\mathrm{NO}_{x}$ and $\mathrm{PM}$ conversion efficiency with a minimum impact on fuel penalty.

\section{APPROACH}

As part of this program, various $\mathrm{NO}_{x}$ aftertreatment technologies including non-thermal plasma, $\mathrm{NO}_{\mathrm{X}}$ adsorber, and active lean $\mathrm{NO}_{\mathrm{X}}$ in conjunction with active reductant injection were investigated first to select the best $\mathrm{NO}_{x}$ technology for emission control subsystem integration and development. Subsystem integration and development activities included catalyst formulation for high $\mathrm{NO}_{x}$ conversion over an increased catalyst/exhaust gas temperature range, catalyst structure for increased exhaust gas residence time on active catalyst sites, and an understanding of the various factors that cause deactivation of the catalyst. Fuel reformulation concepts and diesel-fuel-based onboard hydrocarbon cracking strategies were investigated as a means to increase the activity of the hydrocarbons introduced into the catalyst systems. Even with the availability of low sulfur (<15ppm) diesel fuels, the development of a sulfur management scheme is still critical for some $\mathrm{NO}_{x}$ reduction catalysts to prevent catalyst poisoning and deactivation. The application of a $\mathrm{SO}_{\mathrm{x}}$ trap that can be regenerated offline or periodically replaced was explored.

PM emissions were addressed by developing a catalyzed particulate filter or the combination of a catalyzed particulate filter with supplemental heating. Particulate filter catalysts have been successfully formulated for heavy-duty applications with passive regeneration. However, with the lower exhaust temperatures encountered in a light-duty application, an active regeneration scheme with supplemental heating was investigated.

At the end of the program, the improved aftertreatment components will be integrated and configured optimally in a system developed for a light-duty application. This system will then be calibrated and tested in a controlled environment on a light-duty vehicle.

\begin{tabular}{|c|c|c|}
\hline Configuration & DIATA & ISB \\
\hline No. of Cylinders & $\begin{array}{c}4 \text { Valves/Cylinder } \\
\text { Central Injector }\end{array}$ & $\begin{array}{c}4 \text { Valves/Cylinder } \\
\text { Central Injector }\end{array}$ \\
\hline No. of Valves & 4 & 6 \\
\hline Displacement & 16 & 24 \\
\hline Bore x Stroke & $70 \times 78 \mathrm{~mm}$ & $102 \times 120 \mathrm{~mm}$ \\
\hline Bore/Stroke Ratio & 0.90 & 0.85 \\
\hline Compression Ratio & $19.5: 1$ & $19: 1$ \\
\hline Maximum BMEP & 16 bar & 19 bar \\
\hline Fuel system & HPCR & VP44/HPCR \\
\hline Air Handling System & VG Cooled EGR & VG/WG Cooled EGR \\
\hline
\end{tabular}

Figure 1. Test engine specifications.

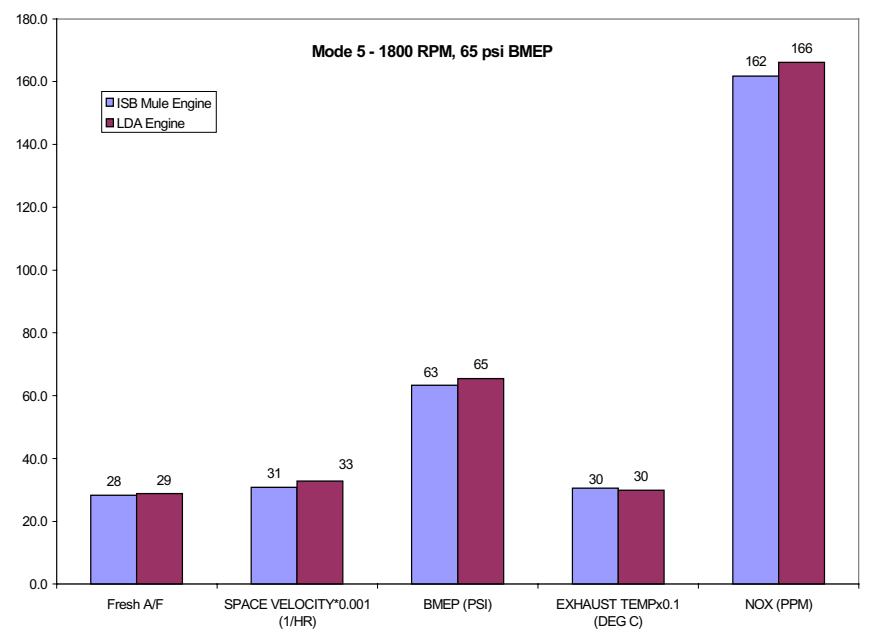

Figure 2. Exhaust characteristics comparison.

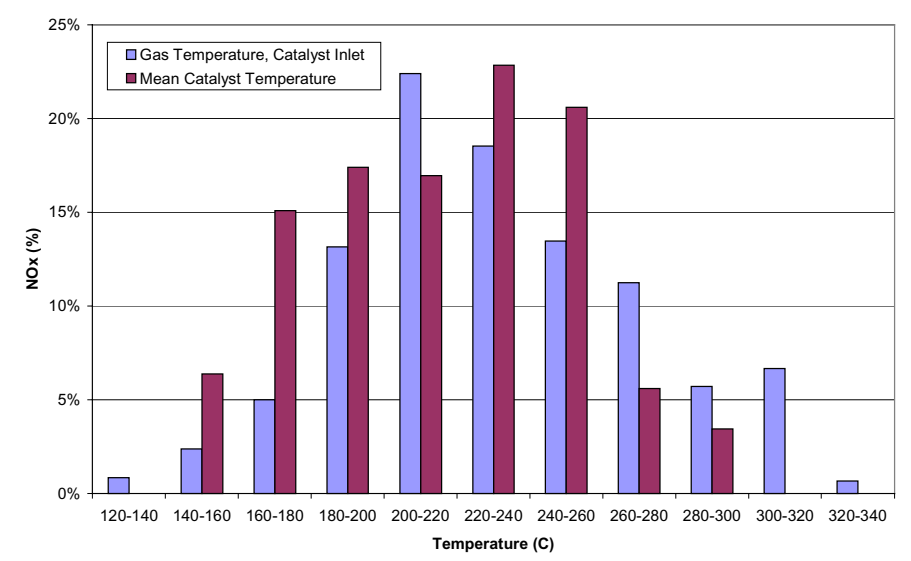

Figure 3. FTP-75 emission cycle temperature breakdown.

\section{$\mathrm{NO}_{\mathrm{X}}$ TECHNOLOGY ASSESSMENT AND SELECTION}

As mentioned earlier, in phase I of this project, the three $\mathrm{NO}_{x}$ reduction technologies including plasma assisted catalytic $\mathrm{NO}_{x}$ reduction, active lean $\mathrm{NO}_{x}$ catalyst, and adsorber catalyst technology using intermittent rich conditions for $\mathrm{NO}_{x}$ reduction were investigated in parallel in an attempt to select the best $\mathrm{NO}_{x}$ control approach for light-duty aftertreatment subsystem integration and development. The investigation included preliminary 
design and analysis, critical lab/engine experiments, and ranking then selection of $\mathrm{NO}_{x}$ control technologies against reliability, up-front cost, fuel economy, service interval/serviceability, and size/weight. The results of this investigation are summarized below.

Non-Thermal Plasma - The principle of the non-thermal plasma for $\mathrm{NO}_{x}$ control is to pass the exhaust gas through a reaction chamber where a rapid electrical pulse of short duration $(25 \mathrm{kV}, 28 \mathrm{MHz}, 10$ nano-second) is introduced as shown in Figure 4. The non-thermal plasma generates electrons, ions, and radicals in the exhaust stream. The active particles then react with NO molecules to form $\mathrm{NO}_{2}$ molecules that are reduced over a catalyst. Figure 5 shows the results of $\mathrm{NO}_{x}$ conversion with diesel fuel as a reductant. Higher levels of $\mathrm{NO}_{\mathrm{x}}$ reduction have been obtained with propene as shown in Figure 6. Models and test results have shown that $\mathrm{NO}_{\mathrm{x}}$ reduction in the presence of oxygen is not possible by plasma alone [1]. Additional technology such as selective catalytic reduction (SCR) is necessary to reduce $\mathrm{NO}_{x}$ to $\mathrm{N}_{2}[2,3]$. The key findings of the PACR technology are summarized below.

\section{Positives}

- Conversion of $\mathrm{NO}$ to $\mathrm{NO}_{2}$ at low temperatures, without $\mathrm{SO}_{2}$ to $\mathrm{SO}_{3}$ oxidation $[4,5]$

- Can enhance $\mathrm{NO}_{x}$ conversion at low temperatures

- Can use diesel fuel as reductant

- Simple reductant injection strategy similar to active lean $\mathrm{NO}_{\mathrm{X}}$

Negatives

- Additional power required for plasma generation

- Very low space velocity/very large catalyst volume required for high conversion efficiency, a $40 \% \mathrm{NO}_{x}$ reduction was achieved with 90 liter SCR catalyst

- Potential safety issues due to high voltage/possible EMI generation

- Benefit of non-thermal plasma decreased as the temperature increased. No benefit was observed at temperatures greater than $300^{\circ} \mathrm{C}$

- Evidence of $\mathrm{NO}_{x}$ adsorption as significant $\mathrm{NO}_{x}$ consumption pathway

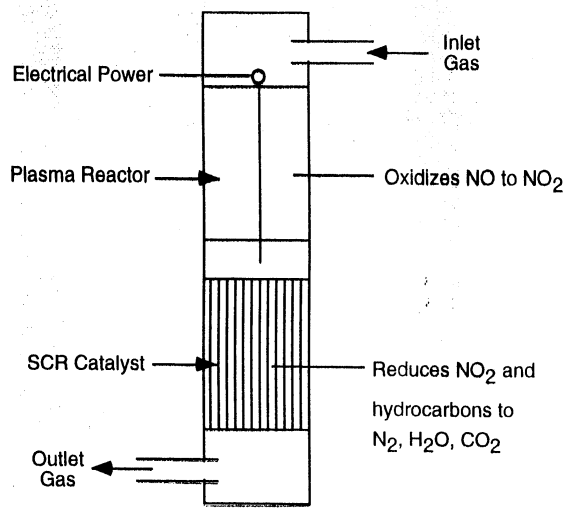

Figure 4. Schematic of plasma assisted catalytic reduction system (PACR).
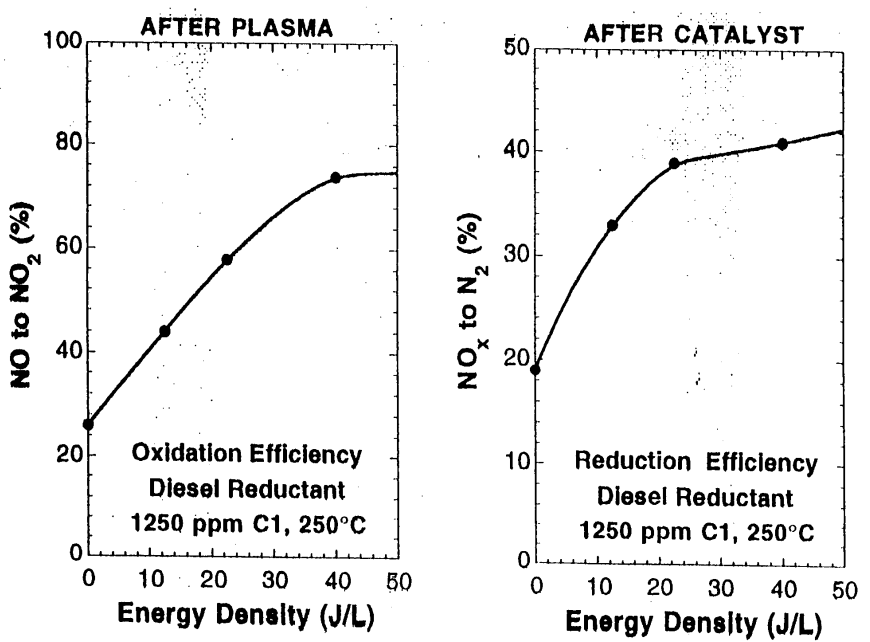

Figure 5. $\mathrm{NO}_{x}$ reduction with $\mathrm{PACR}$ system using diesel fuel as a reductant. Diesel fuel with $\sim 3 p p m$ sulfur used as engine fuel and reductant.
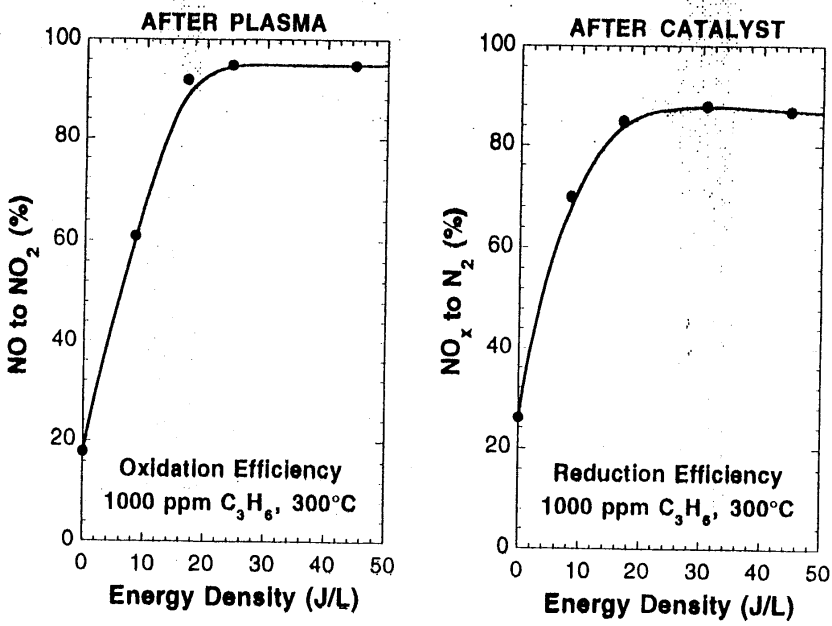

Figure 6. PACR of real diesel exhaust using propene reductant. Diesel fuel with $\sim 3 p p m$ sulfur used as engine fuel.

Active Lean $\mathrm{NO}_{x}$ Catalyst - There are several types of lean $\mathrm{NO}_{x}$ catalysts currently under development by many catalyst companies [6]. The general trend is to use two types of catalysts to cover the temperature range between $200^{\circ} \mathrm{C}$ to $500^{\circ} \mathrm{C}$, as shown in Figure 7 [7]. The low temperature catalyst is a platinum on alumina $\left(\mathrm{Pt} / \mathrm{Al}_{2} \mathrm{O}_{3}\right)$ and the higher temperature catalyst is a copper exchanged zeolite (Cu/ZSM5) [8]. The steadystate combined effectiveness could be as high as 50$60 \%$ of $\mathrm{NO}_{\mathrm{x}}$ removal with the addition of reformulated diesel fuel in front of the catalyst as a chemical reductant [9]. The addition of fuel would have to be controlled such that the right amount of fuel can be added over the engine operating conditions where most $\mathrm{NO}_{x}$ is generated. A breadboard control system and a low pressure fuel injection system were developed to evaluate and understand the potential of lean $\mathrm{NO}_{x}$ catalyst technology. A breadboard ISB engine was used to test an optimized low temperature lean $\mathrm{NO}_{x}$ catalyst under transient FTP-75 cycle conditions. Instead of using a chassis dynamometer, the engine was installed in a CVS test cell and a simulated FTP-75 cycle was run with a specified engine speed and load history obtained from 
computer simulation of a typical Dodge Ram as shown in Figure 8. The transient speed and load history was validated on an actual chassis dynamometer test of a Dodge Ram vehicle with an ISB engine. Since human inputs were minimized with well specified engine speed and load history in the CVS test cell, the repeatability of test results was significantly improved. Over the FTP-75 cycle, the mean catalyst temperature varied between 150 and $300^{\circ} \mathrm{C}$. Only hot cycles were tested. The catalyst size was selected to be 14 liters, representing about 2.5 times engine displacement. Current certification fuel ( $350 \mathrm{ppm}$ sulfur) was used for the engine and supplemental exhaust fuel injection. The transient $\mathrm{C}_{1} / \mathrm{NO}_{\mathrm{x}}$ ratio target was set to be around 9 to 12 , representing about 4 to $6 \%$ fuel penalty. An average $\mathrm{NO}_{x}$ conversion efficiency of $38 \%$ was obtained in the test as shown in Figure 9. The key findings of the active lean $\mathrm{NO}_{x}$ catalyst technology are summarized below.

\section{Positives}

- Can use diesel fuel as reductant (diesel fuel can be added to exhaust or in-cylinder)

- A $38 \% \quad \mathrm{NO}_{x}$ conversion efficiency was demonstrated with diesel fuel as injection reductant

- Simple injection strategy with low complexity for implementation

- Potential low cost solution for very clean diesel with ultra-low engine out emissions (less than $1.0 \mathrm{~g} / \mathrm{kW}$-hr NO $\mathrm{N}_{\mathrm{x}}$

- Precious metal catalyst is only slightly inhibited by $\mathrm{H}_{2} \mathrm{O}$

Negatives

- High $\mathrm{NO}_{x}$ conversion to $\mathrm{N}_{2} \mathrm{O}$ (about $50-60 \%$ of the $\mathrm{NO}_{x}$ reduced), $\mathrm{N}_{2} \mathrm{O}$ is a green house gas

- Poor selectivity, needs excess HC

- High sulfate formation rates at high temperature for high sulfur fuel. Not an issue with future very low sulfur fuel

- Requires combination of different catalysts to cover the whole exhaust temperature range for FTP-75 and US-06 cycles

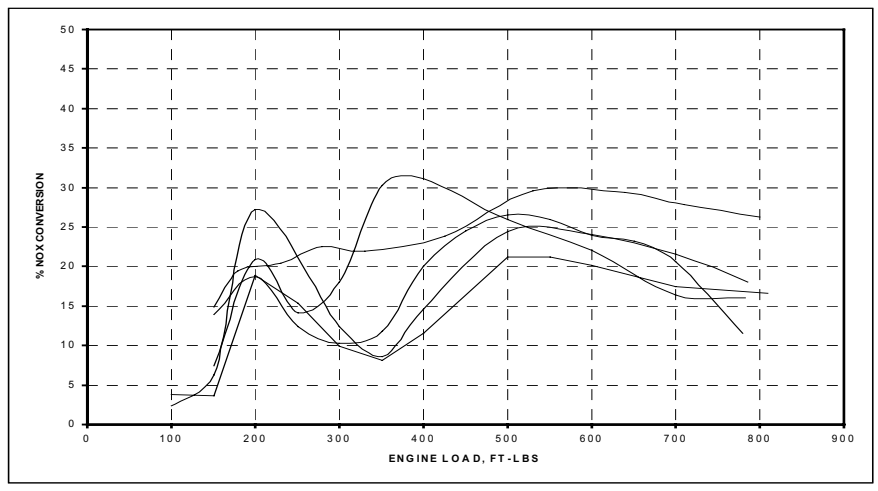

Figure 7. Combining precious metal and base metal catalysts to increase $\mathrm{NO}_{x}$ reduction over a wide temperature range.
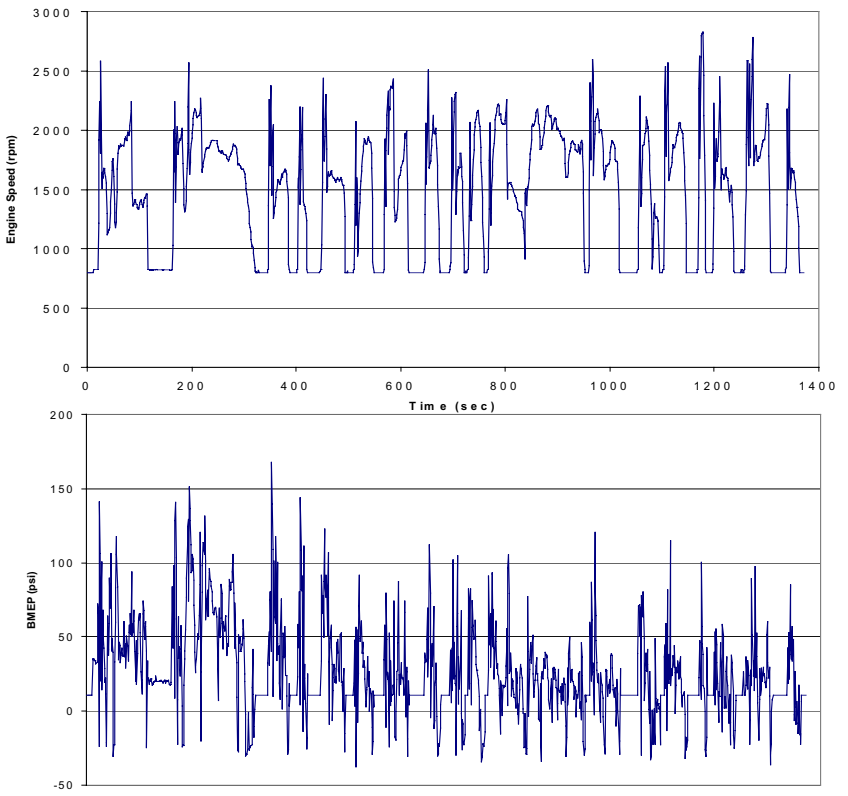

Figure 8. FTP-75 simulated transient cycle.

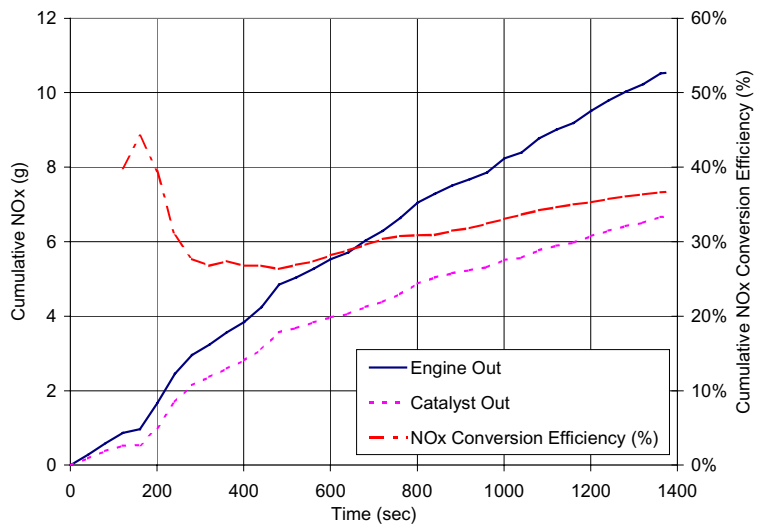

Figure 9. Breadboard ISB over simulated FTP-75 cycle with lean $\mathrm{NO}_{x}$ catalyst.

$\mathrm{NO}_{x}$ Adsorber - $\mathrm{NO}_{x}$ adsorber technology relies on removal of $\mathrm{NO}_{x}$ from the exhaust under lean conditions by adsorption, followed by periodic regeneration of the adsorbent along with reduction of the released $\mathrm{NO}_{\mathrm{x}}$ under rich conditions. This alleviates the need for maintaining a given $\mathrm{C}_{1} / \mathrm{NO}_{\mathrm{x}}$ ratio under transient and fluctuating exhaust $\mathrm{NO}_{x}$ levels, as in the case of the lean $\mathrm{NO}_{x}$ catalyst. For current state-of-the-art catalysts, the lean adsorption step entails the reaction of an acidic gas $\left(\mathrm{NO}_{2}\right)$ with a basic adsorbent (alkaline earth oxide, e.g. $\mathrm{BaO}$ ) to form a nitrate or nitro-species. Since engine-out $\mathrm{NO}_{X}$ is primarily $(90 \%) \mathrm{NO}$ it must first be oxidized to $\mathrm{NO}_{2}$ over a Pt-based catalyst. When the effective capacity of the adsorber is reached, the $\mathrm{NO}_{x}$ is released by a pulsed introduction of enough $\mathrm{HC}$ reductant (e.g. diesel fuel) to establish a rich environment and under this condition the $\mathrm{NO}_{\mathrm{x}}$ is reduced to $\mathrm{N}_{2}$ over a conventional three-way catalyst. In this way, no $\mathrm{N}_{2} \mathrm{O}$ is produced. The operating temperature range of the baseline $\mathrm{NO}_{\mathrm{X}}$ adsorber catalyst is about $300-420^{\circ} \mathrm{C}$. The low limit is due to the light-off of the catalytic $\mathrm{NO}$ to $\mathrm{NO}_{2}$ oxidation step and the upper limit is related to thermal desorption of $\mathrm{NO}_{2}$ from the $\mathrm{BaO}$. Steady-state engine tests using 
low sulfur fuel $(\sim 3 p p m)$ have shown that greater than $95 \% \mathrm{NO}_{x}$ removal can be attained in the temperature range between 320 and $420^{\circ} \mathrm{C}$ using a repeated cycle of 30 seconds lean absorption followed by a 1 second rich regeneration/reduction at an exhaust $A / F$ ratio of $9: 1$, as shown in Figure 10. Because of the supplemental HC's injected during the rich regeneration/reduction pulse, there will be a fuel penalty associated with $\mathrm{NO}_{x}$ adsorber catalysts. The $\mathrm{NO}_{x}$ adsorber catalysts are generally stable to the hydrothermal conditions encountered in diesel exhaust. However, the adsorbent function (e.g. $\mathrm{BaO}$ ) is extremely susceptible to deactivation from sulfur oxides in the exhaust by the formation of $\mathrm{BaSO}_{4}$ [10]. The sulfate thus blocks the adsorption sites intended for $\mathrm{NO}_{2}$ [11]. The result is rapid deactivation. One of the key enablers for $\mathrm{NO}_{\mathrm{x}}$ adsorber catalysts is the availability of ultra low sulfur diesel fuel. A sulfur level of zero would be the best, but is probably not practical [12]. The availability of low sulfur $(<15 \mathrm{ppm})$ diesel fuel together with the application of a $\mathrm{SO}_{x}$ trap to protect the $\mathrm{NO}_{x}$ adsorber may be critical to this technology. The key results of the $\mathrm{NO}_{x}$ adsorber catalyst technology are summarized below.

\section{Positives}

- Potential for high $\mathrm{NO}_{x}$ conversion (> $90 \%$ steadystate, $>83 \%$ transient)

- Wide temperature range of peak operation (320 to $420^{\circ} \mathrm{C}$ ), yet not low enough for light-duty applications

- Can use diesel fuel as reductant, easier enforcement/anti-tampering control

- No infrastructure issues (as with urea distribution) Negatives

- Rapidly poisoned by sulfur from the fuel and lube, and $\mathrm{NO}_{\mathrm{x}}$ conversion efficiency decreases at a rate of approximately $0.1 \%$ per hour with $11 \mathrm{ppm}$ sulfur fuel, a $\mathrm{SO}_{x}$ trap will be required.

- Rich operation of injected hydrocarbon leading to high fuel penalty, HC slip, and SOF particulate make

- Partial flow regeneration adds complexity but offers lower fuel economy penalty

- Complex reductant injection/control system

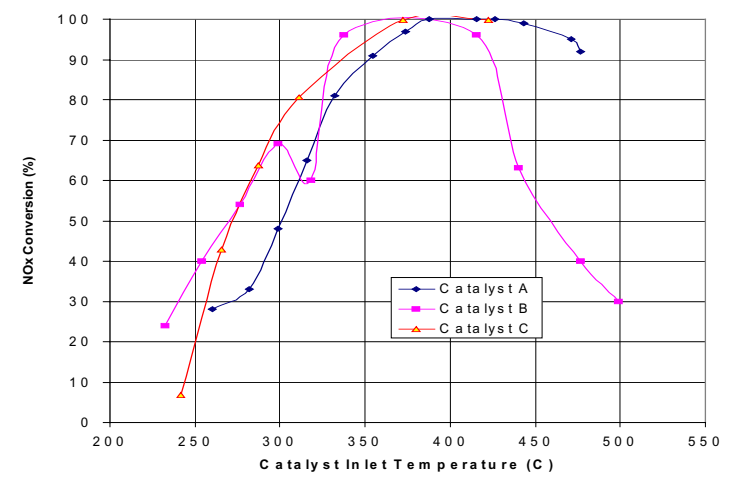

Figure 10. Benchmarking - $\mathrm{NO}_{\mathrm{x}}$ adsorber performance.

\begin{tabular}{|c|c|c|c|c|c|c|c|}
\hline & $\begin{array}{l}\text { ProgramEnissions } \\
\text { Target Capability }\end{array}$ & Reliability & \begin{tabular}{|c|} 
Fuel \\
Eoonomy
\end{tabular} & $\begin{array}{c}\text { UpFrort } \\
\text { Cost }\end{array}$ & $\begin{array}{l}\text { Service Interval/ } \\
\text { Servicedbility }\end{array}$ & \begin{tabular}{|c|} 
Sizel \\
Weight
\end{tabular} & $\begin{array}{l}\text { Composite } \\
\text { Soore }\end{array}$ \\
\hline Weighting Fador & & 10 & 9 & 9 & 7 & 5 & \\
\hline PACR & $\mathrm{No}$ & 3 & 3 & 3 & 3 & 2 & $0^{*}$ \\
\hline SCRHC & $\mathrm{Nb}$ & 5 & 4 & 5 & 5 & 5 & $0^{*}$ \\
\hline NOxAdsarber & Yes & 4 & 5 & 4 & 4 & 4 & 169 \\
\hline
\end{tabular}

Figure 11. Assessment of $\mathrm{NO}_{x}$ aftertreatment technologies (3.2g/kW-hr BSNO ${ }_{x}$ engine out).

NOx Technology Selection - As part of the technology selection process, the ranking of $\mathrm{NO}_{x}$ technologies against reliability, up-front cost, fuel economy, service interval/serviceability, and size/weight was made, as shown in Figure 11. The results indicated that the best $\mathrm{NO}_{x}$ control approach for LDV and LDT applications is the $\mathrm{NO}_{x}$ adsorber catalyst. Both active lean $\mathrm{NO}_{x}$ and PACR technologies are currently not capable of achieving the high conversion efficiency required for DOE/PNGV program objectives. The efficiency requirements for the PNGV program for $\mathrm{NO}_{x}$ and $\mathrm{PM}$ are given in Figure 12. The best $\mathrm{NO}_{x}$ conversion efficiency achieved for active lean $\mathrm{NO}_{x}$ and PACR was about $40 \%$. A decision was made to select adsorber catalyst technology for further development and aftertreatment subsystem integration.

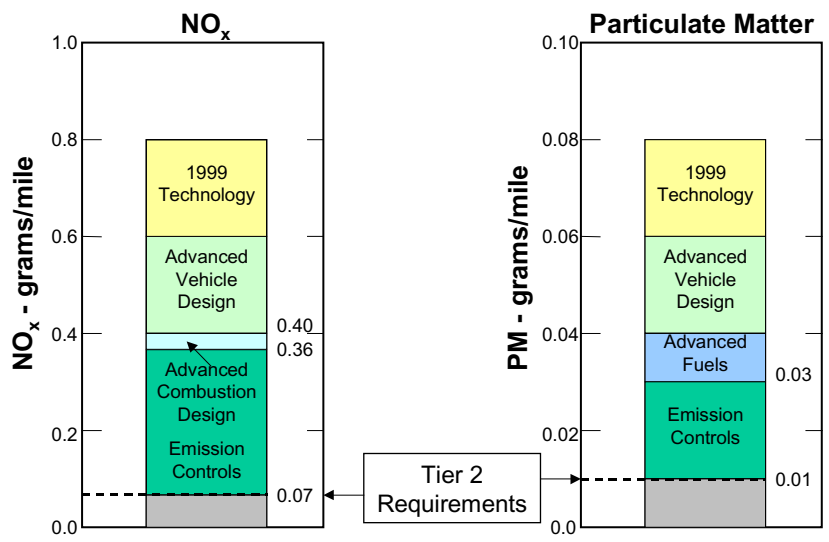

Figure 12. Strategies for achieving emission reductions objectives in lightweight passenger vehicles.

The most critical area for further development of $\mathrm{NO}_{\mathrm{X}}$ adsorber technology is sulfur management. Developing a more sulfur tolerant catalyst, or a sulfur management scheme will be required even if $15 \mathrm{ppm}$ sulfur fuel is available. Another important development area is the hydrocarbon utilization or means to reduce the required fuel penalty. This will involve determination of the effectiveness of various reductants, development of injection systems to provide an optimized reductant, and development of methods to determine what is being delivered to the catalyst [13]. Closely linked to these methods will be the development of a control system which determines when regeneration is required, and the optimum fuel quantity to deliver for the regeneration event [14]. From the material development side, efforts have been focused on lower temperature conversion of 
$\mathrm{NO}$ to $\mathrm{NO}_{2}$, and improving storage capacity in order to reduce catalyst volume.

\section{EXHAUST SULFUR MANAGEMENT}

As shown in Figure 10 previously, the $\mathrm{NO}_{\mathrm{x}}$ adsorber catalysts have achieved high $\mathrm{NO}_{x}$ reduction levels using very low sulfur $(<3 p p m)$ diesel fuels during steady-state conditions. However, the degradation of adsorber performance due to sulfur poisoning remains an issue and needs to be addressed. $\mathrm{SO}_{\mathrm{x}}$ competes for active $\mathrm{NO}_{x}$ adsorption sites to form thermodynamically stable compounds that require an extremely high temperature $\left(>650^{\circ} \mathrm{C}\right)$ and reductant to regenerate the adsorber. The impact of fuel sulfur levels on $\mathrm{NO}_{x}$ conversion efficiency is given in Figure 13. The results indicate that even with the availability of $15 \mathrm{ppm}$ sulfur diesel fuels, an effective exhaust sulfur management scheme is required to keep emission control devices operating near their peak effectiveness. To better understand the effect of adsorber sulfur loading and performance degradation, exhaust sulfur concentration was mapped over a wide range of engine speed and load conditions. The results, as shown in Figure 14, indicate that in addition to the fuel sulfur, the sulfur in the lube oil also plays a major role in adsorber sulfur loading and performance degradation. There are two paths that are currently being explored for sulfur management by Cummins: (1) the use of a $\mathrm{SO}_{\mathrm{x}}$ trap that can be regenerated offline or replaced periodically, and (2) the use of diesel fuel and high temperature to desorb the sulfates. An assessment of each system is summarized below.

\section{Disposable/Offline Regenerable}

- High adsorption capacity for sulfur

- High selectivity toward sulfur adsorption

- No release of secondary emissions from trap

- Usable life of $\mathrm{SO}_{\mathrm{x}}$ trap is dependent on sulfur level in fuel and lube oil

- Good protection of adsorber catalyst from sulfur poisoning during misfueling

- Good technology for light-duty applications - small size, low cost, and limited useful life requirement

$\mathrm{NO}_{x}$ Adsorber Desulfation Catalyst

- Integrated $\mathrm{NO}_{\mathrm{x}}$ trap and $\mathrm{SO}_{\mathrm{x}}$ trap function on one catalyst, does not require separate $\mathrm{SO}_{x}$ trap

- Requires on-board high temperature exhaust management to release sulfur from catalyst (> $\left.650^{\circ} \mathrm{C}\right)$

- Additional fuel penalty will be incurred during desulfation process

- Desulfation involves release of secondary emissions hydrogen sulfide and/or sulfur dioxides

- Catalyst material development required compromise among $\mathrm{NO}_{x}$ storage \& conversion, $\mathrm{SO}_{x}$ storage \& release, and catalyst thermal durability

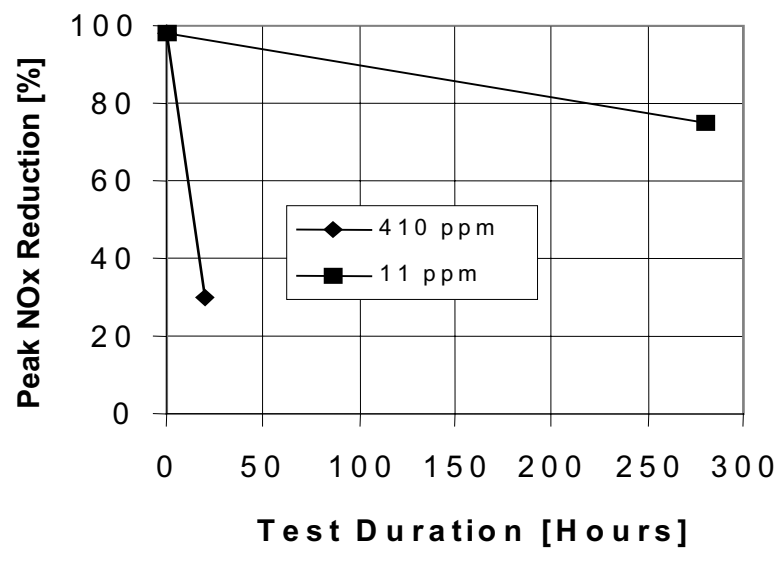

Figure 13. Impact of fuel sulfur levels on $\mathrm{NO}_{X}$ conversion efficiency, ISB engine, $\mathrm{V}_{\mathrm{CAT}} / \mathrm{V}_{\mathrm{ENG}}=2.5$.

(Arco ECD Fuel, Premium Blue Engine Oil)

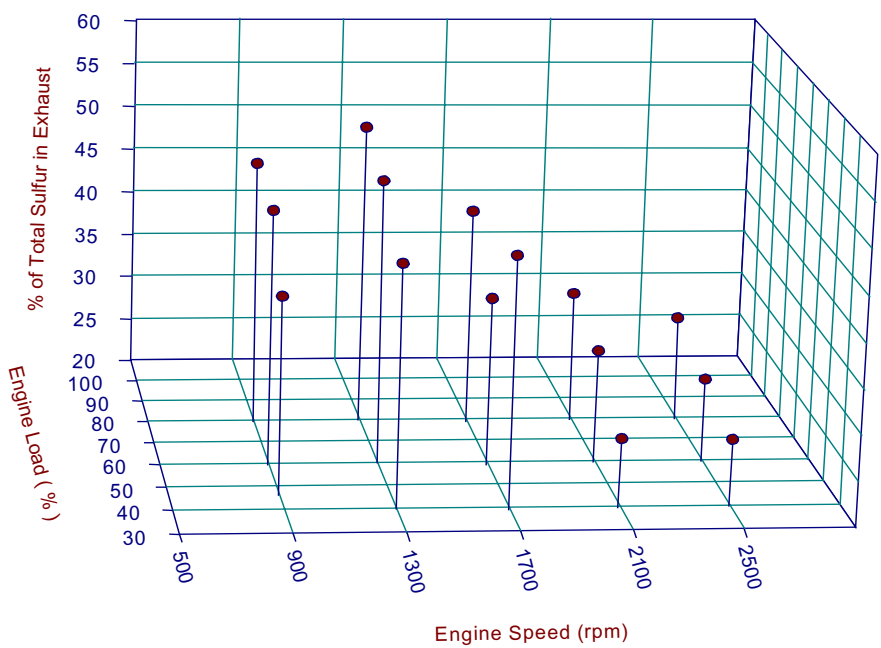

Figure 14. Contribution of lube oil to exhaust sulfur concentration; fuel sulfur $\sim 12 \mathrm{ppm}$, lube sulfur 5000ppm.

In this program, the effort was focused on developing a $\mathrm{SO}_{x}$ trap having sufficient capacity to protect the $\mathrm{NO}_{x}$ adsorber catalyst for at least 20,000 miles before the $\mathrm{SO}_{\mathrm{X}}$ trap would need to be changed. The $\mathrm{SO}_{\mathrm{x}}$ trapping efficiency needs to be near $100 \%$ all the time (<10ppb break-through), and the stored $\mathrm{SO}_{\mathrm{x}}$ should not be released during the hottest driving conditions and during rich transient operation for $\mathrm{NO}_{\mathrm{x}}$ regeneration. The current development path uses a formulation containing base metals. $\mathrm{A} \mathrm{SO}_{\mathrm{X}}$ trap with a $20 \mathrm{gm} \mathrm{SO}_{2} / \mathrm{l}$ capacity, and an estimated 15,000 mile lifetime before change-out has been demonstrated as shown in Figure 15. Alternate substrates with high pore volume are being investigated to provide increased capacity. A global $\mathrm{SO}_{2}$ adsorption model is also being developed to describe the sulfur trap behavior and to correlate the operating conditions and catalyst characteristics effects on the trapping performance. The model combines adsorption kinetics and mass transfer process in a single equation and is able to express adsorption rate in both kinetics and mass transfer dominated regimes. 


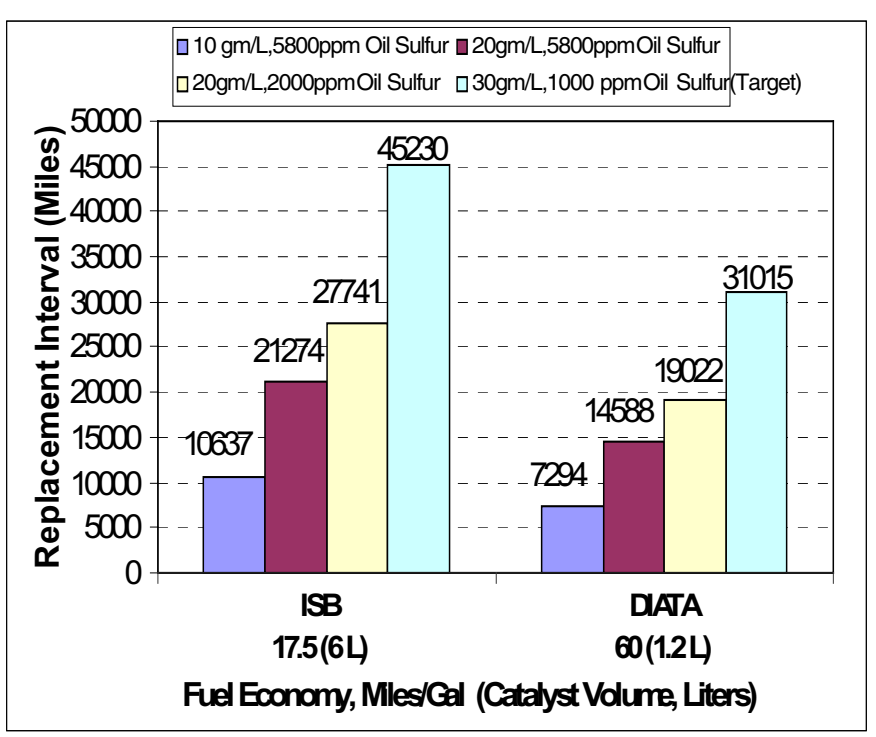

Figure 15. $\mathrm{SO}_{\mathrm{X}}$ trap replacement / offline regeneration interval.

\section{ADSORBER CATALYST FORMULATION DEVELOPMENT AND REDUCATANT SCREENING}

Progress has been made on the adsorber formulation development. Engine test results, as shown in Figure 16, indicate that the $\mathrm{NO}_{x}$ conversion verse temperature curves are nearly identical between ISB and DIATA exhaust aftertreatment systems. This suggest that a fundamental and "displacement-size" transparent understanding can be made on EAS technology development. Figure 16 also illustrates that formulation development has extended catalyst operation by about $100^{\circ} \mathrm{C}$ lower. However, due to diesel fuel oxidation limitations, the low temperature light-off of an adsorber may not be expected below $200^{\circ} \mathrm{C}$. Two alternatives have been analyzed to improve low temperature conversion of $\mathrm{NO}_{x}$ adsorbers: (1) using a reformer to generate reductants which can operate at lower temperatures and (2) raising exhaust temperatures through engine or exhaust heat management so that diesel fuel may be used directly as the reductant.

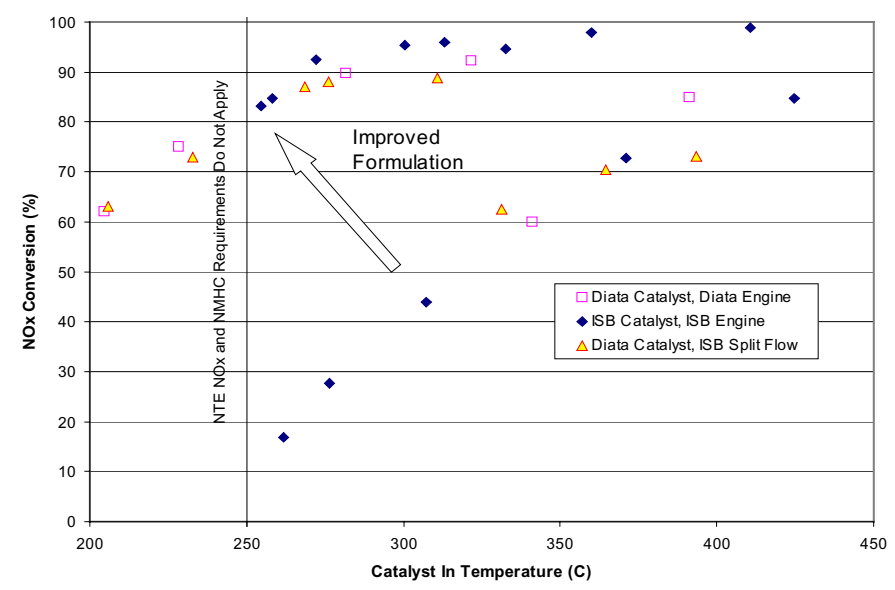

Figure 16. $\mathrm{NO}_{\mathrm{x}}$ adsorber performance comparison.
The reformer produces $\mathrm{H}_{2}$ and $\mathrm{CO}$, which are active reductants even at $180^{\circ} \mathrm{C}$. Reactor test results indicate that $\mathrm{H}_{2}$ is the best reductant, followed by a mixture of $\mathrm{H}_{2}$ and $\mathrm{CO}$, followed by $\mathrm{CO}$. Short straight chain $\left(\mathrm{C}_{4}-\mathrm{C}_{8}\right)$ hydrocarbons are not good reductants for adsorber catalysts (see Figure 17). So for low temperature operation of $\mathrm{NO}_{x}$ adsorbers, either a reformer can be used or the exhaust catalyst-in temperature can be raised to above $200^{\circ} \mathrm{C}$ with engine or exhaust heat management. Several reformer technologies are being procured, and will be used for critical performance testing. Calculations show that all the optimum catalytic partial oxidation (CPO) operating conditions without coking cannot be met under certain engine operating conditions. This testing will help understand the impact of coking on hydrogen production. Use of a reformer for proper reductant regeneration has the potential to allow regeneration of the $\mathrm{NO}_{\mathrm{x}}$ adsorber at temperatures as low as $180^{\circ} \mathrm{C}$. The impact of reductant types on $\mathrm{NO}_{x}$ adsorber low temperature performance is given in Figure 18.

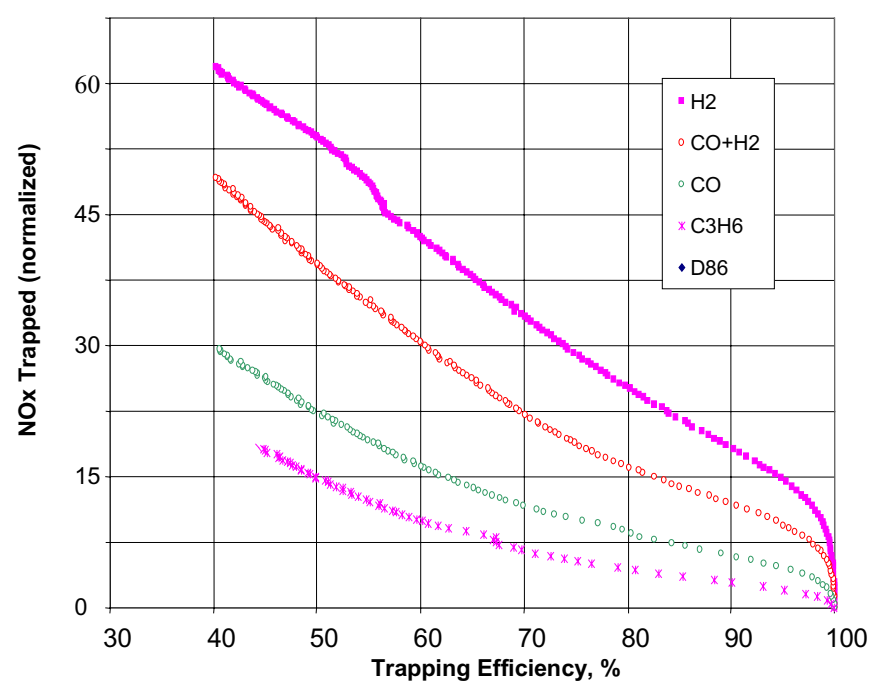

Figure 17. Impact of reductant type on $\mathrm{NO}_{x}$ adsorber trapping capacity vs. efficiency tradeoff @ $225^{\circ} \mathrm{C}$.

\begin{tabular}{|l|c|c|c|c|}
\hline \multirow{2}{*}{ Reductant } & \multicolumn{4}{|c|}{ Cycle NOx Conversion \% } \\
\cline { 2 - 5 } & $\mathbf{2 5 0 ^ { \circ }} \mathbf{C}$ & $\mathbf{2 2 5}^{\circ} \mathbf{C}$ & $\mathbf{2 0 0}^{\circ} \mathbf{C}$ & $\mathbf{1 8 0}^{\circ} \mathbf{C}$ \\
\hline D86 diesel & 92 & 81 & 58 & 5 \\
\hline $\mathbf{C O}$ & 100 & 100 & 93 & 81 \\
\hline $\mathbf{C O} / \mathbf{H}_{\mathbf{2}}=\mathbf{3}$ & 100 & 100 & 98 & 85 \\
\hline $\mathbf{C O} / \mathbf{H}_{\mathbf{2}}=\mathbf{1}$ & 100 & 100 & 100 & 95 \\
\hline $\mathbf{H}_{\mathbf{2}} / \mathbf{C O}=\mathbf{3}$ & 100 & 100 & 100 & 95 \\
\hline $\mathbf{H}_{\mathbf{2}}$ & 100 & 100 & 100 & 95 \\
\hline
\end{tabular}

Figure 18. Impact of reductant types on $\mathrm{NO}_{x}$ adsorber low temperature performance.

\section{DIESEL PARTICULATE FILTER AND ACTIVE RGENERATION}

Conventional particulate filters that have been catalyzed have exhibited 85 to $90 \%$ reductions in PM 
demonstrating that filter technology can achieve the required levels (Figure 19). With the proper choice of catalyst material, this device has the added advantages of providing reduction in $\mathrm{HC}$ and $\mathrm{CO}$ emissions, as well as PM. Catalyzed particulate filters (CPF) have been successfully formulated for HD diesel applications which achieve passive regeneration. Nevertheless, the passive filter regeneration is not robust, and susceptible to cold climates and light-duty cycles. Cummins has conducted a 3+ year demonstration at New Jersey Transit (NJT) with a cumulative total of over 1.1 million miles and over 82,000 hours. The projected catalyzed particulate filter life on NJT buses is 125,000 miles (8000hrs) and is influenced by ash accumulation. Low ash oil formulations are likely to increase filter life and improve catalyst performance. Catalyzed particulate filters are a passive system which require the engine exhaust temperature to periodically be high enough to regenerate the filter [15]. In addition, one must balance between soot loading rate, engine duty cycle, filter size, and ambient temperature. Typically, application screening must be performed prior to installing the particulate filter on the vehicle, and at least $10 \%$ of the duty cycle must be spent with filter inlet temperatures above $315^{\circ} \mathrm{C}$. Figure 20 shows the schematic of a DOC and catalyzed particulate filter. Catalyzed particulate filters have been successfully applied, but:

- All field tests have been carefully examined prior to installing a particulate filter

- All testers are staying away from applications that do not meet specific criteria

- It is not expected that passive filters will work for all environments and all duty cycles

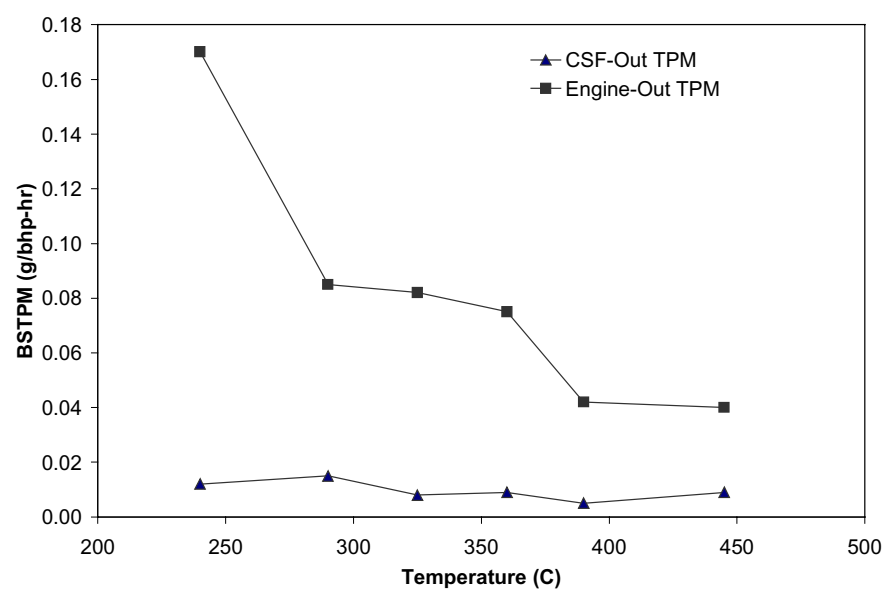

Figure 19. PM emission control from catalyzed particulate filter, ISB engine, $V_{\mathrm{CAT}}=12 \mathrm{l}, 200 \mathrm{cpsi}$.

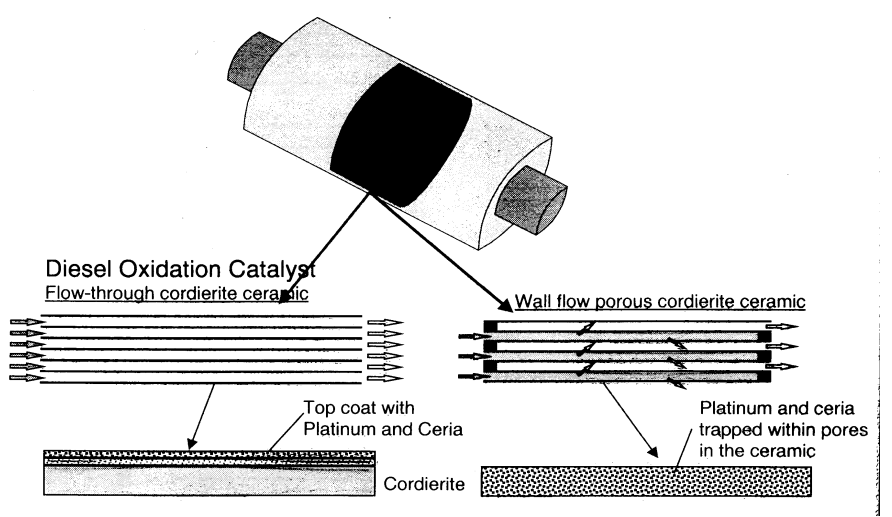

Figure 20. Diesel oxidation catalyst and catalyzed particulate filter schematic.

The key areas of development include developing a catalyst formulation with improved low temperature performance, exploring synergies between particulate and $\mathrm{NO}_{x}$ aftertreatment strategies, and determining the need for supplemental heating $[16,17]$. A supplemental heating system may be required to help the CPF get through those portions of the duty cycle where temperature is too low to achieve a high rate of particulate burning to prevent soot accumulation.

Another characteristic of passive regeneration of particulate filters is uncontrolled regeneration. Uncontrolled regeneration of particulate filters can occur when the filter is loaded with soot, and undergoes an event during the duty cycle that initiates soot combustion in the filter. After the soot begins to combust, if the duty cycle is such that the vehicle goes to a stop, idle, or engine motoring condition, producing a low exhaust flow condition, the filter may overheat, and uncontrolled regeneration and subsequent filter failure will occur. The main factors that influence uncontrolled regeneration of particulate filters include: soot loading level, exhaust temperature, exhaust flow, $\mathrm{O}_{2}$ concentration, $\mathrm{NO}_{2}$ concentration, and catalyst formulation. Engine results have shown that low precious metal loading filters are more prone to undergo uncontrolled regeneration than filters with high levels of precious metals (Figure 21). This is directly related to slower soot burning rates associated with low precious metal loading filters.

\begin{tabular}{|c|c|c|c|c|}
\hline \multicolumn{3}{|c|}{} & \multicolumn{2}{c|}{800 RPM Idle Speed } \\
\hline Filter Size (in.) & PM Loading & Soot Loading & Tout & FAIL ? \\
\hline (Dia x Length) & (gms/cu.ft Pt) & (gms/liter) & $\left({ }^{\circ} \mathbf{C}\right)$ & \\
\hline & & & & \\
\hline $11.25 \times 12$ & 2 & 15 & $1000^{*}$ & Yes (Melting) \\
\hline & & 14 & 993 & Yes (Melting) \\
\hline & & 12 & 814 & No \\
\hline & & 10 & 525 & No \\
\hline & & & & \\
\hline $10.5 \times 12$ & 2 & 10 & 827 & Yes (Possible Cracking) \\
\hline & & 7 & 492 & No \\
\hline & & & & No \\
\hline & 50 & 14 & 634 & No \\
\hline & & 10 & 555 & \multicolumn{2}{c|}{} \\
\hline
\end{tabular}

Figure 21. Results of uncontrolled regeneration experiments. 
Recent test results with microwave regeneration for active particulate filter regeneration indicate that similar to passive regeneration, active regeneration is most efficient when the filter is regenerated at lower soot loading levels $[18,19]$. At high soot loading levels, even with active regeneration, the particulate filter may experience an uncontrolled regeneration, which may result in failure of the filter. Using a $1 \mathrm{~kW}$ microwave for regeneration results in relatively fast soot burning, approximately 10 minutes to regenerate to clean filter condition as compared to 30 minutes for passive regeneration with a $50 \mathrm{~g} / \mathrm{ft} 3 \mathrm{Pt}$ catalyzed particulate filter (Figure 22). For some systems, good control of the regeneration event is obtained by using an auxiliary air supply for the oxidant [18]. A summary of microwave technology for particulate filter regeneration is given below.

\section{Positives}

- Fundamental advantages of the heating process over conventional methods in achieving uniform heating and low power consumption - volumetric and selective heating nature of microwaves

- Heating elements are not in direct contact with exhaust environment, adding to longer life of the components

- Non-catalyzed particulate filter possible

- High control of the soot regeneration event, with increased flexibility to cover a wider span of duty cycles

Negatives

- System development is still in elementary stages and the technology progress has been slow

- Reliability/durability of systems still not known

- Complex heating process

- Requires very low flow rates, requires bypass system or supplemental air supply control

- Uncontrolled regeneration of particulate filter is still possible if strategy is not optimized

- System is not easily scalable from small engine to larger engines

- Requires additional electrical load on vehicle, may require modifications to the alternator system

- Safety issues due to microwave leakage

In order to determine the most efficient, cost effective, active Diesel Particulate Filter (DPF) system, a technology selection process was initiated. There are two different approaches to active DPF regeneration: (1) using engine management for additional heat from combustion to achieve high exhaust temperatures, and (2) using exhaust heat management systems to apply heat to the DPF. The focus of the technology selection was exhaust heat management with the following systems: electrical heating systems, burner systems, microwave systems, and catalytic systems. The performance of each active technology was measured based on regeneration efficiency, regeneration duration, factors affecting uncontrolled regeneration, total system cost, and fuel penalty. The main objective of the downselection process was to identify the most efficient, durable, and cost effective exhaust heat management for active DPF. The results of the technology selection process are given in Figure 23. Critical experiments will be designed to investigate the selected DPF system further. As part of this testing, an advanced catalyzed particulate filter is being tested with a precat upstream to evaluate the advantage of $\mathrm{NO}$ to $\mathrm{NO}_{2}$ function and catalyst exothermic reaction in terms of balance point temperature (BPT). BPT results for advanced CPF, and advanced CPF with precat are shown in Figure 24. The precat with advanced CPF gave a 40 to $50^{\circ} \mathrm{C}$ reduction in the balance point temperature and better regeneration performance.

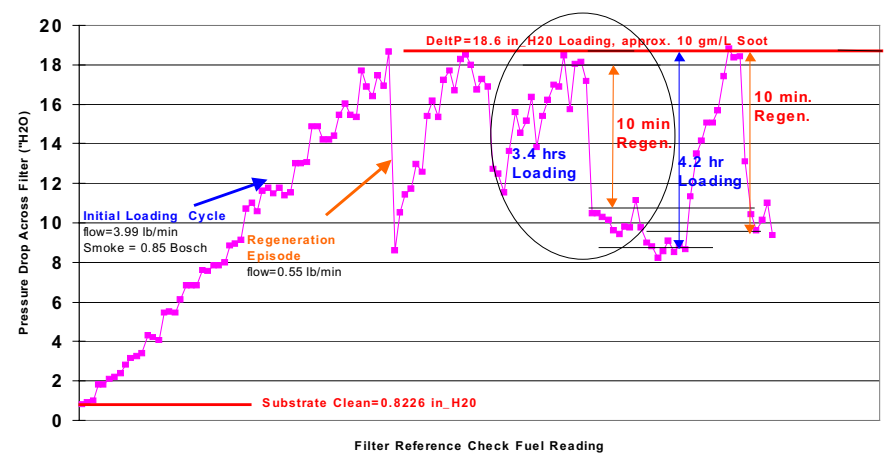

Figure 22. Microwave regeneration of particulate filter.

\begin{tabular}{|c|c|c|c|c|}
\hline & Microwave & Bumer & Eectric & Catalytic \\
\hline A Systemlnitial Cost/Size/Packaging & 3 & 3 & 2 & 1 \\
\hline B System Reliability/Durability & 2 & $\overline{4}$ & 3 & 1 \\
\hline C. System Performance & 3 & 1 & 2 & 4 \\
\hline D. System Controls & 1 & 2 & 3 & 3 \\
\hline E Supplier Interaction/System Maturity & 4 & 3 & 1 & 2 \\
\hline F. System Service Maintenance & 2 & 3 & 4 & 1 \\
\hline G. system Safety & 2 & 3 & 2 & 1 \\
\hline Overall Ranking & 3 & 4 & 2 & 1 \\
\hline $1=$ Best $\quad 4=$ Worst & \multicolumn{3}{|c|}{ Dounselected } & $\begin{array}{c}\text { Oitical } \\
\text { Experiments }\end{array}$ \\
\hline
\end{tabular}

Figure 23. Results of active DPF technology selection.

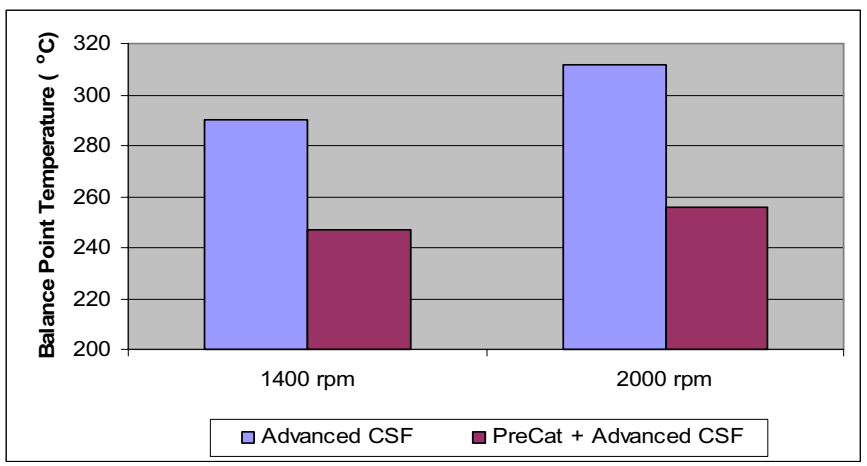

Figure 24. Effect of precat on CPF balance point temperature.

The benefits of using a catalytic system for particulate filter regeneration are many, it is a relatively simple system, low cost, and has synergistic opportunities with 
the rest of the aftertreatment system. For instance, the CPF can be placed downstream of the $\mathrm{NO}_{x}$ adsorber to make use of the heat generated during regeneration of the $\mathrm{NO}_{x}$ adsorber. In this configuration, the CPF can also make use of the $\mathrm{HC}$ slip across the $\mathrm{NO}_{x}$ adsorber, which will cause an additional exotherm with the CPF itself. There can also be synergies by placing the CPF upstream of the $\mathrm{NO}_{x}$ adsorber. An assessment of each configuration is summarized below.

Positives of Placing CPF Downstream of $\mathrm{NO}_{\mathrm{X}}$ Adsorber

- CPF can use heat generated across the adsorber during $\mathrm{NO}_{X}$ regeneration event

- $\mathrm{CPF}$ can make use of $\mathrm{HC}$ slip from the $\mathrm{NO}_{\mathrm{x}}$ adsorber, which will cause an additional exotherm within the CPF itself.

Negatives of Placing CPF Downstream of $\mathrm{NO}_{X}$ Adsorber

- Removal of $\mathrm{NO}_{2}$ from the exhaust stream, $\mathrm{NO}_{2}$ has been proven to be a very good oxidizer of soot $[20,21]$.

- $\mathrm{NO}_{\mathrm{x}}$ adsorber is exposed to "dirty" exhaust, and may face possibility of plugging.

Positives of Placing CPF Upstream of $\mathrm{NO}_{x}$ Adsorber

- Clean exhaust conditions for the $\mathrm{NO}_{x}$ adsorber

- $\mathrm{NO}$ to $\mathrm{NO}_{2}$ oxidation which will assist the function of the $\mathrm{NO}_{x}$ adsorber trapping

Negatives of Placing CPF Upstream of $\mathrm{NO}_{X}$ Adsorber

- $\mathrm{CPF}$ is exposed to cool exhaust temperatures, which may hamper CPF regeneration

- High temperature of CPF regeneration might exceed the maximum material limits of the $\mathrm{NO}_{x}$ adsorber material, causing sintering, and degradation of the catalyst function.

If one extends this thought process to the full conclusion, the best configuration for an exhaust aftertreatment device is to combine or integrate the functions of the separate components on to one single substrate. In this manner, the maximum synergistic effect can be achieved for catalytic functions, as well as heat management. This will also result in a very compact, packageable system.

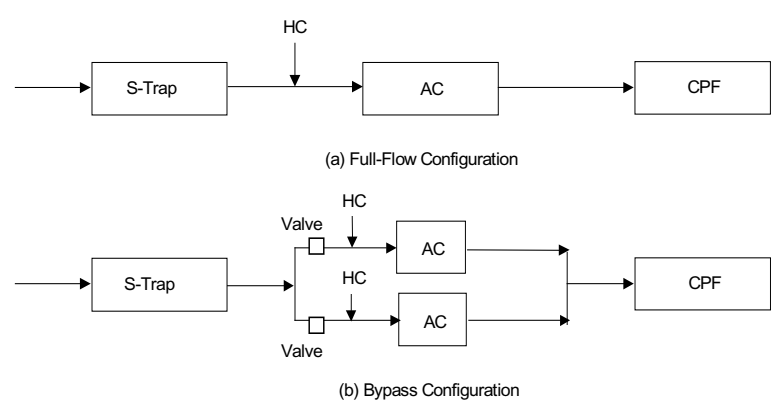

Figure 25. Exhaust aftertreatment system configurations: (a) full-flow, (b) bypass.

\section{PRELIMINARY ENGINE TEST RESULTS ON INTEGRATED SO $\times$ /NO $\times$ /PM SYSTEM}

Fuel Penalty and Configuration Impact - Figure 25 shows two exhaust aftertreatment system configurations being investigated. For both configurations, the systems consist of three major catalyst components: $\mathrm{SO}_{\mathrm{x}}$ trap, $\mathrm{NO}_{\mathrm{x}}$ adsorber (AC), and catalyzed particulate filter (CPF). The purpose of the $\mathrm{SO}_{X}$ trap is to capture sulfur in the engine exhaust before entering the $\mathrm{NO}_{x}$ adsorber. In addition to the usual function of trapping particulate matter in the engine exhaust, the catalyzed particulate filter has higher Pt loading to reduce $\mathrm{HC}$ and $\mathrm{CO}$ slip from the $\mathrm{NO}_{x}$ adsorber regeneration as well. The $\mathrm{NO}_{x}$ adsorber is periodically regenerated by injecting low sulfur $(<15 \mathrm{ppm})$ diesel fuel to produce a rich environment for the release of adsorbed $\mathrm{NO}_{x}$ and subsequent conversion to $\mathrm{N}_{2}$.

Under steady-state engine operating conditions, the $\mathrm{NO}_{\mathrm{x}}$ adsorber is normally regenerated at fixed time intervals, for example, every 30 seconds. The quantity of the injected fuel has to be sufficient not only to produce rich conditions $(\lambda<1)$, but also to react with $\mathrm{NO}_{\mathrm{X}}$ desorbed from the catalyst and convert it into $N_{2}$. To ensure this condition is met, the injection quantity is usually based on a catalyst-in $\mathrm{A} / \mathrm{F}$ ratio target lower than stoichiometric (14.6 for diesel fuel), such as $A / F=9$. For diesel engines operating in oxygen rich exhaust conditions $(\lambda>1)$, a significant portion of the injected fuel is used to consume $\mathrm{O}_{2}$ in the exhaust. While laboratory tests have shown that a longer regeneration period can improve regeneration efficiency, this is usually not practical due to proportionally higher fuel penalty associated with the $\mathrm{O}_{2}$ reaction. For this reason, fuel injection is typically limited to produce only a very short rich period, for about 1 to 5 seconds. The effectiveness of the injected fuel to produce conditions favorable for $\mathrm{NO}_{X}$ conversion depends on many factors, such as the fuel injection quantity and flow distribution leading to the $\mathrm{NO}_{\mathrm{x}}$ adsorber.

For the full-flow configuration, as shown in Figure 25(a), all the engine exhaust flows through the $\mathrm{NO}_{x}$ adsorber during both lean and rich periods. The fuel penalty of the $\mathrm{NO}_{x}$ adsorber regeneration can be calculated based on exhaust flow rate, engine $\mathrm{A} / \mathrm{F}$ ratio, regeneration frequency, catalyst-in A/F ratio target, and engine brake specific fuel consumption (BSFC). The calculated injected fuel penalty on the breadboard ISB low- $\mathrm{NO}_{X}$ engine over different steady-state operating conditions for the full flow configuration is given in Figure 26(a). The fuel penalty is highest at high speed and low load conditions, because the exhaust flow rate and engine $\mathrm{A} / \mathrm{F}$ ratio are both higher there. A higher percentage of the injected fuel is used for $\mathrm{O}_{2}$ consumption when the engine $A / F$ ratio is high, usually at low engine loads.

One way to reduce fuel penalty associated with $\mathrm{NO}_{\mathrm{X}}$ adsorber regeneration is to reduce $\mathrm{O}_{2}$ flow during regeneration. This can be accomplished by using the bypass configuration as shown in Figure 25(b). The flow 
after the $\mathrm{SO}_{\mathrm{X}}$ trap is split equally into two bypass legs. Each leg contains one-half of the total $\mathrm{NO}_{x}$ adsorber volume, and each has a fuel injection system in front of the adsorber for regeneration. During regeneration, the flow through the adsorber under regeneration is restricted to below $50 \%$ of the total engine exhaust. For a fixed catalyst-in $A / F$ ratio target, the fuel injection required for regeneration can be proportionally reduced. Figure 26(b) shows the fuel penalty for the ISB breadboard engine when $20 \%$ bypass flow is used during regeneration. Since both bypass legs have to be regenerated in turn, the total fuel penalty is two times the $20 \%$ bypass flow, resulting in a fuel penalty $60 \%$ lower than the full-flow regeneration. In addition, tests have shown that the HC slip after the $\mathrm{NO}_{x}$ adsorber is also lower. This is because space velocity and fuel injection quantity are both lower during bypass, resulting in more complete reaction.

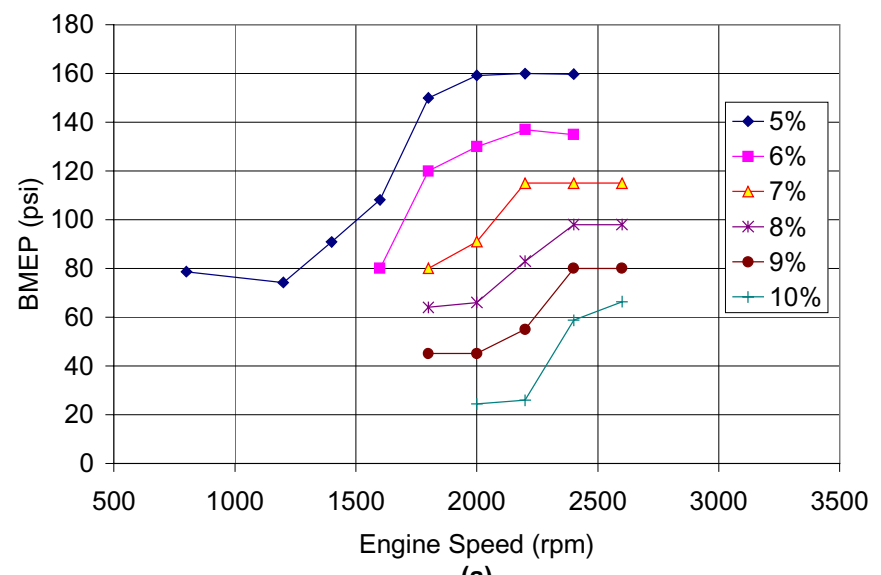

(a)

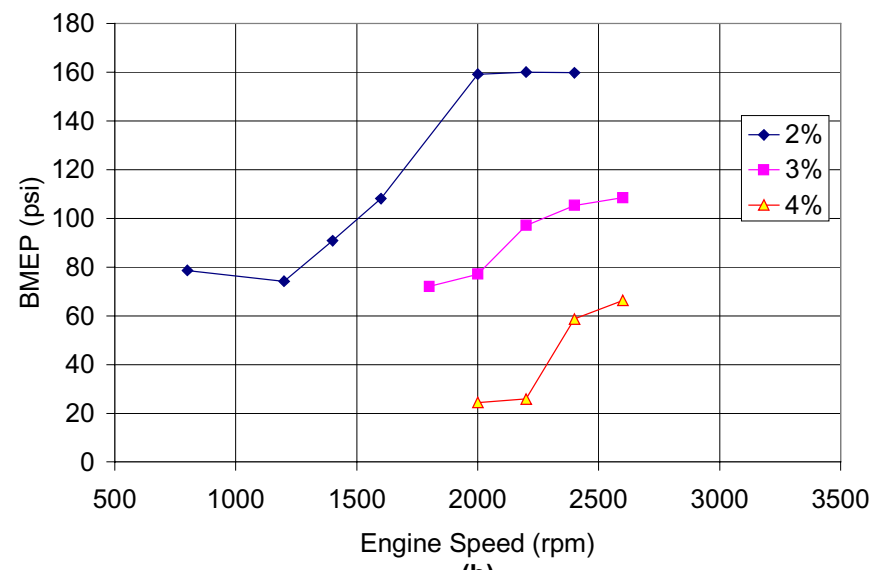

(b)

Figure 26. $\mathrm{NO}_{x}$ adsorber fuel penalty for breadboard ISB under SS operation with 29s/1s regeneration, A/F $=9$ target, (a) Full-flow regeneration, (b) 20\% full-bypass regeneration.

Bypass regeneration is considerably more complex than full-flow. Careful considerations need to be given to additional influencing factors such as the percent of bypass and the duration of bypass both before and after the fuel injection. If the valves remain fully open during regeneration, $50 \%$ of exhaust would pass through each of the bypass legs and no fuel penalty savings would be realized. On the other hand, if the flow were restricted to the maximum (approaching zero) during regeneration, the injected fuel would take considerable time to travel through the catalyst, resulting in a long regeneration period. In the mean time, the temperature of the catalyst would drop toward the ambient due to the lack of heat from the exhaust flow, and lower temperatures reduce the regeneration effectiveness. Simultaneously, the adsorber on the other leg would pass nearly $100 \%$ of engine exhaust flow, resulting in faster $\mathrm{NO}_{x}$ loading. $\mathrm{NO}_{x}$ adsorption efficiency decreases with increasing $\mathrm{NO}_{x}$ loading. In addition, the adsorption would take place at higher space velocity, further reducing the adsorption efficiency. If the catalysts were regenerated in such a way that there is always one catalyst under regeneration, then only one-half of the total adsorber volume is used for $\mathrm{NO}_{x}$ adsorption at any given time, resulting in a poor utilization of the total adsorber capacity. Thus the optimum bypass percentage is somewhere between $0 \%$ and $50 \%$. The bypass period should be made as short as possible, without compromising the regeneration effectiveness. To fully utilize the total catalyst capacity, both $\mathrm{NO}_{x}$ adsorbers should be active most of the time. Extensive tests have been performed, and the results indicate that about 10 to $20 \%$ regeneration bypass is the optimum, and similar NOx conversion efficiency as fullflow regeneration can be maintained with reduced fuel penalty.

The reaction of $\mathrm{HC}$ with $\mathrm{O}_{2}$ and $\mathrm{NO}_{x}$ are both exothermic. If the heat loss to the ambient is minimized, the exothermic heat from $\mathrm{NO}_{x}$ adsorber regeneration can be utilized to raise the temperature not only for the $\mathrm{NO}_{x}$ adsorber, but also the CPF. Since the CPF is placed downstream of the $\mathrm{NO}_{x}$ adsorber, the exit temperature from the $\mathrm{NO}_{\mathrm{x}}$ adsorber is also the inlet temperature for the CPF. Based on current CPF technology, approximately $300^{\circ} \mathrm{C}$ and above inlet temperature is needed to regenerate the CPF continuously. Figure 27(a) shows the typical $\mathrm{NO}_{\mathrm{x}}$ adsorber inlet temperature of the breadboard ISB engine during steady-state conditions. The inlet temperature is generally a strong function of engine load, and a weak function of engine speed. The $\mathrm{NO}_{x}$ adsorber inlet temperature is lower than the engine turbo-out temperature, due to heat transfer to the ambient from components upstream such as the $\mathrm{SO}_{\mathrm{x}}$ trap and exhaust pipe. Improved insulation can reduce this heat loss.

Figure 27(b) shows the CPF inlet temperatures for the $20 \%$ bypass, catalyst-in A/F ratio target of 9 , and $29 \mathrm{~s} / 1 \mathrm{~s}$ regeneration case. The $300^{\circ} \mathrm{C} \mathrm{CPF}$ regeneration limit is moved to lower engine load as compared to Figure 27(a), due to exothermic heat release of the $\mathrm{NO}_{\mathrm{X}}$ adsorber regeneration. The amount of exothermic heat generated is a function of fuel injection quantity and frequency. It is possible to further increase the CPF inlet temperature at low load for active CPF regeneration by increasing the fuel injection quantity or frequency. 


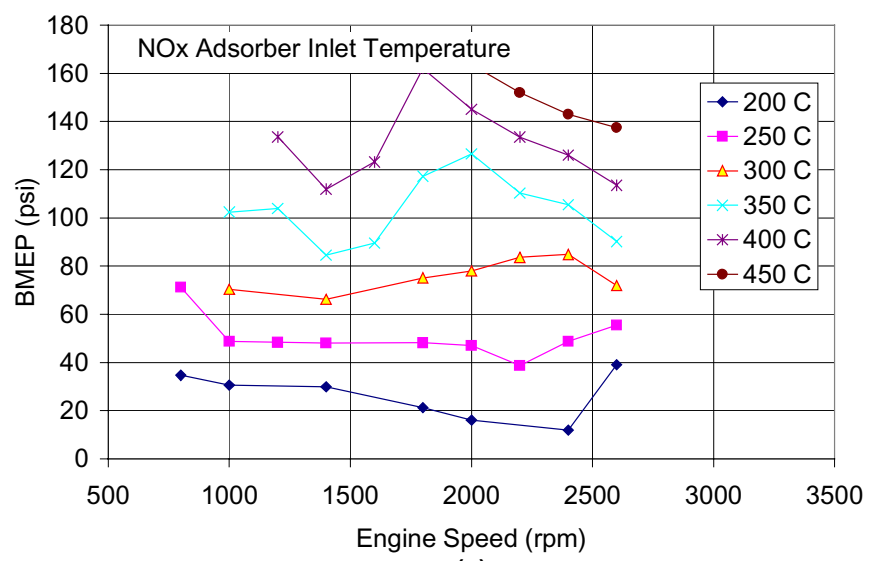

(a)

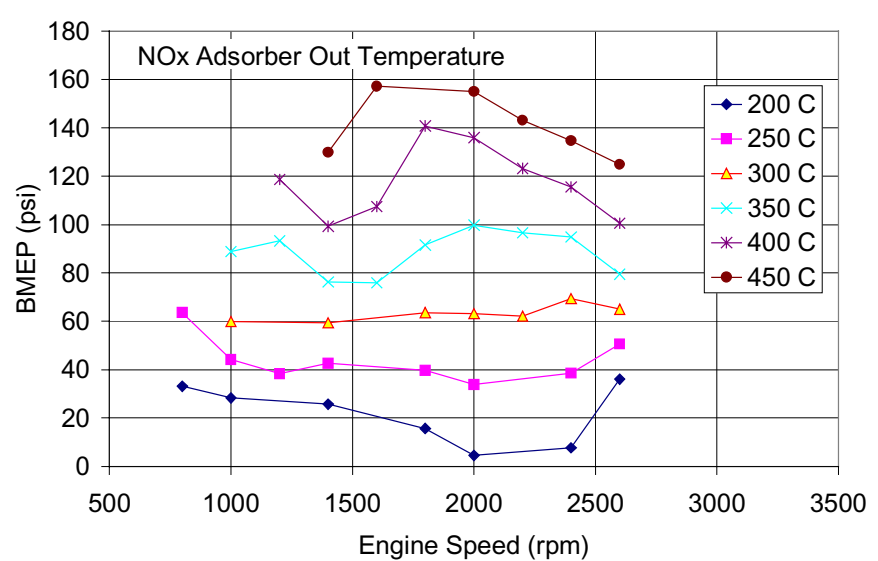

(b)

Figure 27. $\mathrm{NO}_{x}$ adsorber out temperature vs. inlet temperature of a breadboard ISB engine.

Simulated FTP-75 Cycle Transient Test Results - The $\mathrm{NO}_{X}$ adsorber transient test is carried out by using a breadboard ISB engine in a CVS test cell. The FTP-75 cycle is simulated by specifying an engine speed and load history obtained from computer simulation and validated in chassis dynamometer tests of a typical Dodge Ram vehicle.

As compared to steady-state tests, transient tests provide some additional challenges. For example:

- The turbo-out temperature is lower than the steadystate operation of the same engine speed and load due to engine thermal inertia. The effect of thermal inertia of the aftertreatment system also becomes more important, and further reduces the peak temperature at catalyst inlet.

- The initial state of the $\mathrm{NO}_{x}$ adsorber is unknown at the beginning of each FTP-75 cycle. For steady-state tests, this can be overcome by a period of stabilized catalyst operation.

- The exhaust flow condition is varying continuously. It is impractical to pre-determine the regeneration timing and injection quantity, especially in real-world applications.

- For bypass regeneration, the two catalysts can experience different inlet conditions $\left(\mathrm{NO}_{x}\right.$ rate, temperature, etc.), as well as different initial states.
To meet these additional transient testing challenges, a closed-loop regeneration control algorithm using various sensor inputs was implemented with a programmable controller. The regeneration timing and injection quantities are both dynamically determined by the controller during the transient test.

Arco EC-D low sulfur (<15ppm) diesel fuel was used for both the breadboard ISB engine and exhaust injection. A 7 liter $\mathrm{SO}_{\mathrm{X}}$ trap, and a 12.5 liter CPF are arranged as shown in Figure 25. Two 7 liter $\mathrm{NO}_{x}$ adsorbers were used to form a total of 14 liters volume. The adsorbers are either used in series, as in the full-flow configuration of Figure 25(a), or in parallel, as in the bypass configuration of Figure 25(b). Two exhaust valves are used, one on each leg of the bypass system, to regulate the bypass flow.

To illustrate the impact of the initial state of the system, the $\mathrm{NO}_{\mathrm{x}}$ adsorbers were first fully cleaned at a favorable steady-state condition (1400 rpm, $200 \mathrm{ft}-\mathrm{lb})$. Subsequent to the pre-cleaning, a hot FTP-75 cycle was run without exhaust fuel injection. Figure 28 shows a $97 \% \mathrm{NO}_{\mathrm{x}}$ conversion efficiency can be obtained with no fuel penalty on a bypass system. However, this high efficiency can not be sustained. When the tests were repeated without pre-cleaning and regeneration, the $\mathrm{NO}_{x}$ conversion efficiency dropped to around $76 \%$, and then $61 \%$, as the initial $\mathrm{NO}_{x}$ loading at the beginning of each cycle became higher.

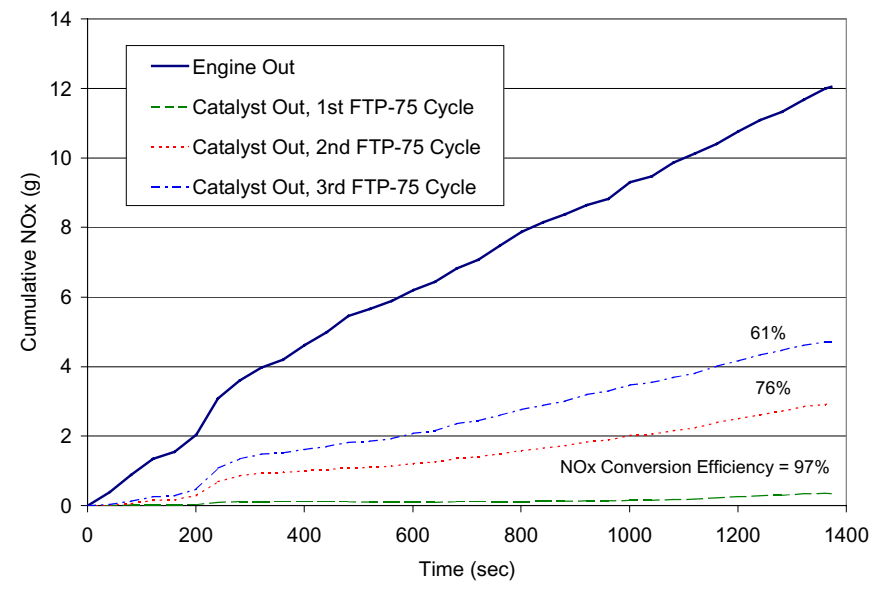

Figure 28. Impact of $\mathrm{NO}_{x}$ adsorber initial state on $\mathrm{NO}_{\mathrm{x}}$ conversion efficiency.

Since the $\mathrm{NO}_{\mathrm{x}}$ adsorber is a storage device, it is necessary to demonstrate the effectiveness of regeneration by maintaining the $\mathrm{NO}_{X}$ conversion efficiency over several FTP-75 cycles without precleaning. The final state of these hot FTP-75 cycles can be used to start the cold FTP-75 cycle the next day. Figure 29 shows the bypass regeneration results of using this approach. Because of the low exhaust temperature, $72 \% \mathrm{NO}_{x}$ conversion efficiency was obtained for the cold-start cycle. For subsequent hot-start FTP-75 cycles, the $\mathrm{NO}_{x}$ conversion efficiency averaged about $87 \%$. The CPF particulate trapping efficiency averaged about $93 \%$. 
Figure 30 shows the cumulative $\mathrm{NO}_{x}$ and conversion efficiency time history of one of the hot-start cycles. At about 200 seconds, there is a drop in the cumulative $\mathrm{NO}_{x}$ efficiency because a period of high space velocity and high $\mathrm{NO}_{\mathrm{x}}$ loading occurs when the catalyst temperature is still relatively low. Subsequent regeneration slowly recovers the $\mathrm{NO}_{x}$ conversion efficiency to the final value.

\begin{tabular}{|l|c|c|c|c|}
\hline & \multicolumn{2}{|c|}{ NOx } & \multicolumn{2}{c|}{ PM } \\
\cline { 2 - 5 } & g/bhp-hr & \% change & g/bhp-hr & \% change \\
\hline Engine Out & 1.20 & & 0.222 & \\
\hline EAS Out, cold & 0.34 & $-72 \%$ & 0.019 & $-91 \%$ \\
\hline EAS Out, hot & 0.15 & $-87 \%$ & 0.011 & $-95 \%$ \\
\hline EAS Out, hot & 0.13 & $-89 \%$ & 0.014 & $-94 \%$ \\
\hline EAS Out, hot & 0.17 & $-86 \%$ & 0.017 & $-92 \%$ \\
\hline EAS Out, hot & 0.18 & $-85 \%$ & 0.016 & $-93 \%$ \\
\hline
\end{tabular}

Figure 29. Transient FTP-75 test results (bypass).

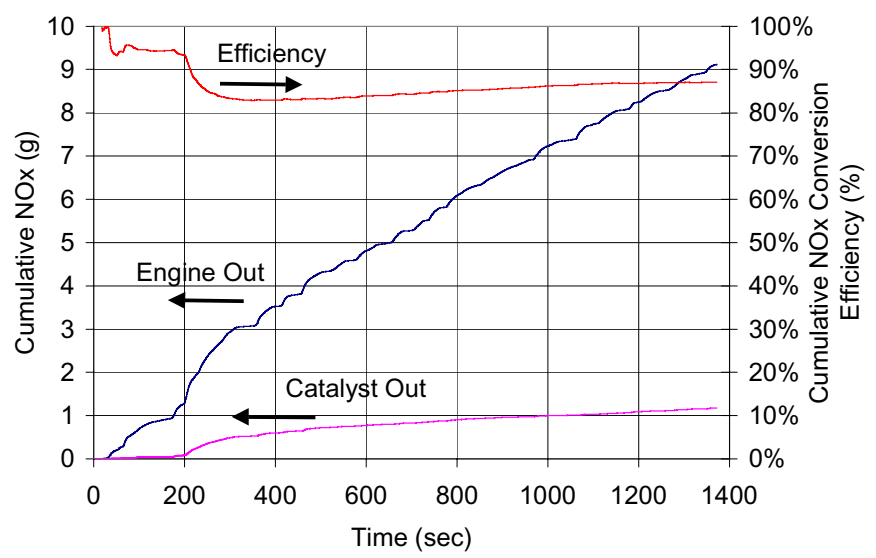

Figure 30. Cumulative $\mathrm{NO}_{x}$ history over a hot FTP-75 cycle for the bypass configuration.

\section{FUTURE WORK AND DIRECTION}

Much progress has been made, but much work still remains to be accomplished. As mentioned previously, sulfur management is one of the most important areas where progress still needs to be made in order to make the $\mathrm{NO}_{\mathrm{x}}$ adsorber technology possible. Increasing the capacity of a replaceable or off-line regenerable trap will be needed to achieve an acceptable service interval. Increased pore volume and other substrate materials are being investigated. Alternatively, investigations into regenerable $\mathrm{NO}_{x}$ adsorbers that will allow the $\mathrm{SO}_{x}$ trapped to be released under high momentarily sustained temperatures will also be explored. Adsorber durability with periodic high temperature $\mathrm{SO}_{\mathrm{x}}$ regenerations will be key to this technology.

Heat management is already an important consideration for LDV and LDT applications. Temperature loss from the turbo-out to the catalyst-in can be detrimental to catalyst performance. Even higher temperature requirements for $\mathrm{SO}_{\mathrm{x}}$ regeneration will add to this importance. Engine-out exhaust temperature manipulation and exhaust system insulation will be required to effectively control the catalyst-in temperatures over the light-duty operating conditions.

Effective use of any reductant added to the exhaust will be key to optimizing catalyst conversion efficiency and minimizing any fuel penalty. Reductant dispersion and concentration are important parameters when selecting placement and spray characteristics of an auxiliary injector. Even though this program is limited to exhaust aftertreatment sub-system development, it is realized that ultimately, any supplemental injector in the exhaust system will have to be evaluated against engine management capability to provide excess hydrocarbon to act as a reductant during regeneration events.

Current development efforts have demonstrated highly efficient $\mathrm{NO}_{x}$ and PM reduction. However, acceptable system cost has not yet been demonstrated. Efforts continue to reduce the size and complexity of the catalyst system, thereby reducing the overall cost. Work continues to investigate individual catalyst size reduction, and catalyst integration or combinations. Enhanced washcoat formulations and more optimal substrate geometry and materials are all under consideration.

While $\mathrm{NO}_{x}$ and $\mathrm{PM}$ control are the main concerns with respect to emissions controls on diesel engines, one does not wish to inadvertently produce any potentially harmful unregulated byproducts as a result of the addition of any new aftertreatment devices. One such concern is the potential for ammonia $\left(\mathrm{NH}_{3}\right)$ generation from adsorbers. There is speculation that $\mathrm{NH}_{3}$ might be formed over a $\mathrm{NO}_{x}$ adsorber catalyst when $\mathrm{HC}$ is injected during regeneration. Testing is planned to evaluate this concern.

And finally, component and system reliability and durability has yet to be investigated thoroughly. Though demonstration is outside the scope of our current program, reliability and durability are always a consideration during our investigation. Both component and system reliability and durability are of great interest to both the manufactures and regulating agencies. During development efforts, we will continue to keep a close watch on any indicators such as failures or performance deterioration to provide some insight into component and system capability.

\section{CONCLUSION}

Results of extensive aftertreatment subsystem design and analysis to date indicate that the best $\mathrm{NO}_{x}$ control approach for LDV and LDT applications is $\mathrm{NO}_{x}$ adsorber technology. An $83 \% \mathrm{NO}_{x}$ reduction efficiency is required to achieve $0.07 \mathrm{~g} / \mathrm{mile} \mathrm{NO}_{\mathrm{X}}$ PNGV vehicle-out emissions. Both active lean $\mathrm{NO}_{x}$ and PACR technologies are not currently capable of achieving the high conversion efficiency required for DOE/PNGV program objectives. An $87 \% \mathrm{NO}_{\mathrm{X}}$ conversion efficiency and 93\% PM 
conversion efficiency have been demonstrated using a breadboard low emission Cummins ISB engine and an adsorber/CPF exhaust configuration on a simulated FTP-75 emission cycle. With the lower exhaust temperatures encountered in a PNGV application, the improvement in $\mathrm{NO}_{x}$ conversion efficiency over a wider exhaust temperature range has also been identified as a critical development task. Significant progress has been made on adsorber formulation development, extending the operation of the catalysts by $100^{\circ} \mathrm{C}$ lower as compared to previous formulations.

Progress has also been made on $\mathrm{NO}_{x}$ adsorber regeneration strategies reducing the fuel injection penalty by 40 to $50 \%$ compared to earlier tests. As part of an early demonstration/validation of $\mathrm{NO}_{x}$ adsorber technology progress, a mobile exhaust aftertreatment subsystem has been prepared for preliminary chassis dynamometer testing on a diesel hybrid electric PNGV vehicle at Argonne National Lab.

Throughout the PNGV EAS project the emphasis has been on a fundamental understanding of aftertreatment technologies. Demonstrations have been focused on repeatable performance and development efforts have been directed towards technologies which have a reasonable chance of meeting EPA anticipated regulations. Much has been accomplished to date, but much work remains in order to deliver the technology to the marketplace.

\section{ACKNOWLEDGMENTS}

Support for this work is provided by the Department of Energy (Contract DE-FC02-99EESOS77) and Cummins Inc. The authors would also like to express sincere appreciation to colleagues, including CZ Wan and Rahul Mital for their help in making this paper possible.

\section{REFERENCES}

1. "Fundamentals Limits on Gas-Phase Chemical Reduction of $\mathrm{NO}_{x}$ in a Plasma" B.M. Penetrante, M.C. Hsiao, B.T. Merritt, and G.E. Voigtlin, 1997 Diesel Engine Emissions Workshop, July 28-31, 1997.

2. "Plasma Assisted Heterogeneous Catalysis for $\mathrm{NO}_{\mathrm{X}}$ Reduction in Lean-burn Engine Exhausts" M.C. Hsiao, B.M. Penetrante, B.T. Merritt, and G.E. Voigtlin, 1997 Diesel Engine Emissions Workshop, July 28-31, 1997.

3. "Plasma Enhanced Selective Catalytic Reduction of NOldx for Diesel Cars", SAE 982428, A.G. Thomas Hammer and Stefan Broer, Oct. 1998.

4. "Limiting Factors and Effect of Sulfur on PlasmaAssisted Catalytic Reduction of $\mathrm{NO}_{x}$ in Light-Duty Vehicle Exhaust" B.M. Penetrante, 1999 Diesel Engine Emissions Workshop, July 5-8, 1999.

5. "Sulfur Tolerance of Selective Partial Oxidation of $\mathrm{NO}$ to $\mathrm{NO}_{2}$ in a Plasma", Non-Thermal Plasma for Exhaust Emission Control: $\mathrm{NO}_{X}, \mathrm{HC}$, and
Particulates, SAE 1999-01-3687, B.M. Penetrante, R.M. Brusasco, B.T. Merrit and G.E. Vogtlin, 1999.

6. "Research Results on Processes and Catalyst Materials for Lean $\mathrm{NO}_{x}$ Conversion", SAE 962041, Axel Konig, etc..., Oct. 1996.

7. "Progress in Sulfur Poisoning Resistance of Lean $\mathrm{NO}_{x}$ Catalysts", SAE 980930, Kenji Arakawa, Satoshi Matsuda, and Hiroo Kinoshita, Feb. 1998.

8. "Development of Zeolite Catalyst to Remove Diesel NOx ", SAE 958386, Masanori Iwasaki, Nobuyuki Ikeya, Masaharu Itoh, Masaaki Itoh, Sep. 1995.

9. "A Diesel Perspective on Lean $\mathrm{NO}_{x}$ Catalysts" B.G. Bunting, M.J. Cunningham, R.K. Miller, 1998 Diesel Engine Emissions Workshop, July 5-9, 1998.

10. "NOx Adsorber Catalysts Applied to Heavy Duty Diesel Test Cycles" M.J. Cunningham, 1999 Diesel Engine Emissions Workshop, July 5-8, 1999.

11. "Impact of Sulfur on $\mathrm{NO}_{x}$ Trap Catalyst activity Study of the Regeneration Conditions", SAE 982607, M. Guyon, F. Blejean, C. Bert, Ph. Le Faou, Oct. 1998.

12. "Effect of Fuel Sulfur and Aromatics on Diesel Exhaust Emissions", SAE 918221, Shinji Kobayashi, Tohru, Masahiko Hori, 1991.

13. "Catalytic $\mathrm{NO}_{x}$ Reduction by Diesel Fuel Spray Method", SAE 4-14-2-82, Satoshi Sumiya, Seiji Makino, Kozo Ogasawara, Apr. 1993.

14. "Regeneration Strategies for $\mathrm{NO}_{\mathrm{X}}$ Adsorber Catalysts", SAE 972845, Owen Bailey, Danan Dou and Gregory W. Denison, Oct. 1997.

15. "Future Application of Catalyzed Soot Filters" R.K. Miller, M.J. Cunningham, S. Ren, 1998 Diesel Engine Emissions Workshop, July 5-9, 1998.

16. "Effects of Sulfur on Performance of Catalytic Aftertreatment Devices", SAE 920557, Robert J. Farrauto and John J. Mooney, 1992.

17. "Save the Diesel Fueled Engine: a Clean Diesel Engine with Catalytic Aftertreatment The alternative to Alternative Fuels, John Mooney and Joe Wolfgang, Apr. 1993.

18. Popuri, S. et al., "Development of a Microwave Assisted Regeneration System for A Ceramic Diesel Particulate Trap System," SAE Paper 1999-01-3565, 1999.

19. Nixdorf, R.D., et al., "Microwave-regenerated Diesel Exhaust Particulate Filter," SAE Paper 2001-010903, 2001.

20. Cooper B.J., Thoss, J.E.,"Role of NO in Diesel Particulate Emission Control", SAE 890404, 1989.

21. DECSE, 2000a. "Phase I Interim Data Report No. 4: Diesel Particulate Filters", U.S. DOE, January 2000,

\section{DEFINITIONS, ACRONYMS, ABBREVIATIONS}

AC: Adsorber Catalyst

A/F: Air to Fuel Ratio

BPT: Balance Point Temperature 
CARB: California Air Resource Board

CIDI: Compression Ignition Direct Injected

CPF: Catalyzed Particulate Filter

CVS: Constant Volume Sampling

DOC: Diesel Oxidation Catalyst

DOE: Department of Energy

DPF: Diesel Particulate Filter

EPA: Environmental Protection Agency

LDT: Light-Duty Truck

LDV: Light-Duty Vehicle

LNC: Lean NOx Catalyst

NJT: New Jersey Transit

NOx: Nitrogen Oxides

PACR: Plasma Assisted Catalytic Reduction

PM: Particulate Mater

PNGV: Partnership for a New Generation of Vehicles

SOx: Sulfur Oxides 